\title{
Film Festivalleri ve Turizm İlişkisi: Belgesel Film Yönetmenleri Üzerine Bir Çalışma
}

\author{
Burak Türten (Dr. Öğr. Üyesi) \\ Karabük Üniversitesi Türker İnanoğlu Iletişim Fakültesi \\ burakturten@karabuk.edu.tr \\ Başvuru Tarihi: 15.10.2020 \\ Yayına Kabul Tarihi: 04.01.2021 \\ Yayınlanma Tarihi: 29.01.2021 \\ https://doi.org/10.17680/erciyesiletisim.810902
}

\section{Öz}

Yönetmenler gerek mesleki açıdan gerekse toplum içerisindeki konumları itibariyle kitleleri yönlendirebilme ve etkileyebilme özelliğine sahiptir. Bu özelliklere sahip olan yönetmenler film festivallerinin de önemli paydaşları arasındadır. Bu çalışmada, yönetmenlerin bakış açısıyla turizm kapsamında destekleyici bir ürün olarak ele alınan film festivallerinin düzenlendiği bölgeye ve bölge turizmine katkılarının tespit edilmesi amaçlanmaktadır. Bu amaçla yapılan çalışmada nitel araştırma yöntemi kullanılmış olup veriler görüşme tekniği ile toplanmıştır. Araştırmanın örneklemi kolayda örnekleme yöntemi ile en az 5 film festivaline davet edilmiş ve festival yönetimi tarafından ağırlanmış 12 belgesel film yönetmeninden oluşmaktadır. Elde edilen veriler MAXQDA 2020 nitel analiz programı yöntemi ile içerik analizine tabi tutulmuştur. Çalışma neticesinde yönetmenlerin, turizm kapsamında destekleyici bir ürün olarak ele alınan film festivallerinin düzenlendiği bölgeye ve bölge turizmine olası katkılarına ilişkin vermiş oldukları cevaplar "ekonomik", "sosyo-kültürel" ve "tanıtım/imaj" olmak üzere üç tema altında toplanmıştır. Elde edilen bulgular doğrultusunda film festivallerinin bölge ve bölge turizmine yönelik ekonomik katkıları bölgede ziyaretçi sayısında artış yaratma, sosyo kültürel katkıları bölgeye ait kültürel mirasın tanıtılması ve korunması, son olarak imaj ve tanıtıma yönelik katkıları ise bölgenin ulusal ve uluslararası alanda bilinirliğinin sağlanması üzerine yoğunlaştığı tespit edilmiştir.

Anahtar Kelimeler: Film Festivalleri, Belgesel Film Yönetmenleri, Sinema, Turizm. 


\title{
The Relationship between Film Festivals and Tourism: A Study on Documentary Film Directors
}

\author{
Burak Türten (Asst. Prof. Dr.) \\ Karabük University Faculty of Communication \\ burakturten@karabuk.edu.tr
}

Date Received: 15.10.2020

Date Accepted: 04.01.2021

Date Published: 29.01.2021

https://doi.org/10.17680/erciyesiletisim.810902

\begin{abstract}
Directors can direct and influence the masses both professionally and in terms of their position in society. Directors with these qualities are also among the important stakeholders of film festivals. In this study, it is aimed to determine the contribution of film festivals to the region. So, the qualitative research method was adopted and the data were collected by interview technique. The sample of the research in Turkey with an easy sampling method has been invited to at least 5 film festivals and consists of 12 documentary filmmakers. The data obtained were subjected to content analysis using the MAXQDA 2020 qualitative analysis program method. As a result of the study, the answers given by the directors were collected under three themes: "economic", "sociocultural" and "promotion and image". Firstly it has been determined that the economic contributions of film festivals to the region are to increase the number of visitors in the region. Secondly, it has been realized that the socio-cultural contributions of film festivals to the region are to promote and protect the cultural heritage of the region. And finally, it has been determined that the promotion and image contributions of film festivals to the region are to provide national and international recognition.
\end{abstract}

Keywords: Film Festivals, Documentary Film Directors, Cinema, Tourism. 


\section{Giriş}

Yaşayan bir topluluğun dünya görüşünü, tarihini, kültürel ve sosyal kimliğini sergileyen temalı kutlamalar olarak ifade edilen festivaller (Miller, 2004) en genel tabirle toplumlar ile bireyler arasında ekonomik, kültürel, sosyal, sanatsal açıdan yakınlaşma ve tanıtım sağlayan toplumsal faaliyetlerdir (Bilgili, Yağmur, \& Yazarkan, 2012, s. 117124). Düzenlenme amaçları, içerikleri, organizasyon yapısı, düzenlenen mekân ve zamanın çeşitli olması alan yazında festival kavramı tanımı üzerinde ifade birliğinin oluşturulamamasına ve yazında Akgül (2019) çeşitli tanımlamaların ortaya çıkmasına neden olmuştur. Goldblatt (1997) "toplumsal ve bireysel kimliğin bir parçası olan festivaller için birey, kültürel çevre ve toplum arasındaki bağları güçlendiren bir süreç" tanımlamasını kullanırken, Dimmock \& Tiyce (2001) ise "festivaller toplumun yașam biçiminin değerli yönlerini kutlayan ve kısa süreliğine sahneye konmak için tasarlanan, belirli bir temayı içeren halk oyunlarıdır" șeklinde ifade etmiştir.

Esasen alan yazında yapılan tanımlamalar göstermektedir ki festivaller, topluma ait olan sosyal norm ve değerlerin ifadesi olarak ortaya çıkan ve halkı kapsayan tek seferlik veya belirli aralıklarla tekrarlayan söz konusu bölgeye özgü toplumsal temelli etkinliklerdir. Bunun yanı sıra Litvin ve Fetter (2006) festival kavramını, bir destinasyona turist akışı sağlayan ve bundan dolayı oluşan taleple, o destinasyonda bulunan yerel işletmelere ekonomik talep yaratan etkinlikler şeklinde tanımlayarak festivallerin, ev sahibi topluluklar üzerinde çeşitli etkileri olan küresel turizm ürününün kritik öneme sahip bir bileșeni olduğu üzerine dikkatleri çekmiştir (Pasanen, Taskinen, \& Mikkonen, 2009, s. 112-129). Hiç kuşkusuz festivaller, rekabet avantajı sağlayabilmek için çeşitli çekicilik unsurlarını bünyesinde barındırması gereken bölgelerin turist çekebilmesi ve diğer çekicilik unsurlarını zenginleştirmesi adına önem teşkil eden etkinlikler arasında bulunmakta (Şengül \& Genç, 2016, s. 79-89) ve turizm endüstrisinin önemli bir parçası olarak kabul edilmektedir. Bu sebeple, kendine özgü festivallere sahip olan bölgelerin diğer bölgelere nazaran üstünlük sahibi olduğu söylenebilir.

Ülkeler, şehirler veya ilçeler belirli zaman aralıklarında bölgeye gelen ziyaretçi sayısını ve yerel halkın gururunu arttıran, ekonomik getiri sağlayan ve bölgenin imajını güçlendiren; amaç ve kapsamları çeşitlilik arz eden farklı işlevlerde festivallere ev sahipliği yapmaktadır. Farklı festival türlerinden biri de bir çeşit sanat ve turizm etkinliği olan film festivalleridir. Ulusal ya da uluslararası film festivalleri, düzenlendikleri bölgeler için ayrıcalıklı ekonomik, kültürel değer ve kazanımlar oluşturan küresel ağın birer parçalarıdır. Film festivalleri, farklı filmleri arayan izleyici ile izleyici arayan farklı filmlerin buluştuğu, dünyada pazar arayıșında bulunan farklı türdeki sinemaların ve farklı dünya sinema arayışında olan film dağıtıcılarının bir araya geldiği aracı bir uzamdır (Bikiç Çakar, 2018, s. 70-93). Bu uzamda aracı konumundaki film festivalleri, kültürler arası bakış ilişkilerinin kurulduğu ve korunduğu kültürel matris işlevi görmekle beraber Stringer (2001) insanların merak ve keşfetme dürtüsünü tatmin etme temelini oluşturan, turizm faaliyetlerinin temel yapı taşı olan seyahatlerin tetikleyici bir unsuru konumundadır. Dünya sinemasının kültürel meşruluğunu temin eden film festivalleri dünya sinemalarının görünür kılınmasında önemli görülen birer geçittirler (Öcal, 2013). Bu geçitler vasıtasıyla birbirleriyle etkileşime geçen yerel halk ile film festivali katılımcıları, kültürlerarası karşılıklı anlayış ve hoş görüyü geliştirerek birbirlerinin kültürleri üzerinde olumlu etkiler yaratacaktır.

Düzenlendikleri destinasyonlar için ayrıcalıklı ekonomik ve kültürel kazanım olușturan film festivalleri ve turizm arasındaki bu ilişki doğrultusunda bu çalışmada yönetmenlerin 
bakış açısıyla turizm kapsamında destekleyici bir ürün olarak ele alınan film festivallerinin düzenlendiği bölgeye ve bölge turizmine katkılarının tespit edilmesi amaçlanmaktadır. Yapmış oldukları iş gereği eserleri ile milyonlarca insanı etkileyebilme gücüne sahip olan yönetmenlerin film festivalleri ve düzenlendikleri bölgenin turizm gelişimi hakkındaki görüşleri, film festivallerinin amaçları doğrultusunda yönetilebilmesi ve aynı zamanda düzenlendikleri bölgenin turizm gelişiminin olumlu yönde evrilmesi hususunda önemli görülmektedir. $\mathrm{Bu}$ doğrultuda çalışma kapsamında film festivallerinin düzenlendiği bölgelere ekonomik, sosyo-kültürel ve tanıtım-imaj konusunda sağladığı katkılar incelenecek ve film festivalleri katılımcılarının beklentilerini karşılayacak ve memnuniyet düzeylerini olumlu yönde etkileyeceği düşünülen önerilerde bulunulacaktır.

\section{Tarihsel Bakış Açısıyla Film Festivalleri}

Avrupa, film festivali olgusunun beşiği aynı zamanda küresel film festival ağının merkezi konumundadır. Bu olgu 1930'lu yıllarda 2. Dünya Savaşı öncesindeki jeopolitik durum ve 1940'lı yılların sonu ve 1950'li yılların başında oluşan 2. Dünya Savaşı sonrası yeni siyasi düzen bağlamında oluşmuştur. Dünyanın ilk film festivali ilk kez 1932 yılında Venedik'te Uluslararası Venedik Bienali'nin bir parçası olarak düzenlenen Venedik Film Festivali'dir. İlk olarak 1939 yılı Eylül ayının ilk 3 haftasında düzenlenmesi planlanan ve Venedik Film Festivali'ne alternatif bir festival olarak kurulan Cannes Film Festivali, Almanya'nın 1 Eylül 1939'da Polonya'yı işgal etmesi sebebiyle iptal edilerek faaliyetlerine 1946 yılına kadar ara vermek zorunda kalmıştır (Turan, 2002). Tekrar 1952 yılında düzenlenmeye başlayan Cannes Film Festivali, o günden bu yana Fransız sinemasının köklü varlığını ulusal ve uluslararası arenada yansıtan bir kurum olarak işlevini sürdürmeye devam etmektedir (Mazdon, 2007).

1935 yılında düzenlenmeye başlayan Uluslararası Moskova Film Festivali, Venedik Film Festivali'nden sonra dünyanın en eski ikinci film festivali konumunda olmasına rağmen 1959 yılına kadar devam edebilmiştir. 2. Dünya Savaşı'na kadar Venedik (1932), Moskova (1935) ve Cannes (1939) olmak üzere toplamda 3 film festivali düzenlenmiş; Locarno, Karlovy Vary ve Berlin gibi diğer büyük uluslararası film festivalleri ise 1940’ların sonunda ve 1950’lerin başında oluşan savaş sonrası bir olgu olarak ortaya çıkmıştır (Turan, 2002). Festival sayısının arttığı bir dönem olan 2. Dünya savaşı sonrası hem Amerika'nın kültürel iliş̧ilerinin yoğunlaştığı hem de Hollywood hegemonyasının yükseldiği bir dönem olan 1951 yılında, Berlin Uluslararası Film Festivali kurulmuştur (Mazza \& Pedersen, 2001). Film festivalleri, kısa süre sonra bütün dünyaya hızla yayılmaya başlamıș, Berlin Film Festivali'nden bir yıl sonra Asya kıtasında Hindistan'da (1952) iki yıl sonra Avustralya kıtasında Sidney'de (1954) ve Güney Amerika'da ise Arjantin'de (1954) film festivalleri kurulmuştur (De valck, 2007).

Dünyanın diğer yerlerinde hızlı bir şekilde yeni festivallerin düzenlenmeye başlanmasıyla birlikte film festivallerinde "Kısa film", "Belgesel film" gibi tür bağlamında kategorileşmeler yaşanmaya başlanmıştır. Sayı her gün değişmekte olduğu için günümüzde kaç uluslararası film festivalinin olduğu tam olarak bilinmemekle beraber, küresel ölçekte toplam sayının 3500 civarında olduğu tahmin edilmektedir (Ooi \& Pedersen, 2010). Uluslararası film festivallerini ele alırken Harbord (2009) Avrupa'daki film festivallerinin (ve savaştan sonra oluşan diğer festivallerin) oluşumunu Avrupa'nın savaş sonrası yenilenmesi ve iyileşmesine bağlamıștır. Burada tüm film festivallerinin kuruluş tarihini vermek ve festivallerin küresel bir fenomen haline dönüşünü listelemek asıl amaç değilse de erken dönemde batı dışında da uluslararası film festivallerinin kurulmaya başladığını belirtmek gerekebilir. Burada vurgulanmak istenen listedeki üç festivalin halen dünyadaki en 
büyük ve en iddialı festivaller olarak düzenlenmeye devam ettikleridir. Sırasıyla Venedik, Cannes ve Berlin film festivalleri, diğer film festivallerinin "rekabet etmek istemeyeceği" büyüklükte ve farklı bir kulvardadırlar (Mazza \& Pedersen, 2001). Tablo 1 festivallerin kuruluş sırasını göstermektedir (Ooi \& Pedersen, 2010) .

Tablo 1. İlk Dönem Film Festivallerine Genel Bir Bakıș ${ }^{1}$

\begin{tabular}{|l|l|l|}
\hline 1932 & Venedik Uluslararası Film Festivali & İtalya \\
\hline 1935 & Moskova Uluslararası Film Festivali & Rusya \\
\hline 1939 & Cannes Uluslararası Film Festivali & Fransa \\
\hline 1946 & $\begin{array}{l}\text { Karlovy Vary Uluslararası Film Festivali } \\
\text { Locarno Uluslararası Film Festivali }\end{array}$ & $\begin{array}{l}\text { Çekoslovakya } \\
\text { İsiçre }\end{array}$ \\
\hline 1951 & Berlin Uluslararası Film Festivali & Almanya \\
\hline 1952 & Hindistan Uluslararası Film Festivali & Hindistan \\
\hline 1953 & Donostia-San Sebastian Uluslararası Film Festivali & İspanya \\
\hline 1954 & $\begin{array}{l}\text { Sluslararası Kısa Film Festivali Oberhausen } \\
\text { Mar del Plata Uluslararası Film Festivali }\end{array}$ & $\begin{array}{l}\text { Almanya } \\
\text { Avustralya } \\
\text { Arjantin }\end{array}$ \\
\hline 1956 & Times BFI Londra Film Festivali & İngiltere \\
\hline 1958 & Bilbao Uluslararası Belgesel ve Kısa Filmler Festivali & İspanya \\
\hline
\end{tabular}

Film festivallerinin köklü tarihi ve çeşitliliği göz önünde bulundurulup gerek ulusal gerekse uluslararası alan yazın incelendiğinde, film festivallerini konu edinen kapsamlı çalışmaların yapıldığı görülmektedir. Getz (2010) The nature and scope of festival studies, (2010) tarafından yapılan "The Nature and Scope of Festival Studies" isimli çalışmada da belirtildiği üzere, festivallerle ilgili uluslararası alan yazında 423 adet makalenin olduğu ve bu makalelerin turizm, markalaşma, kent kimliği, festival, festival yönetimi, festivallerin toplum ve kültürle ilişkisi başlıkları altında toplandığı tespit edilmiştir. Yine aynı çalışmada belirtilen 423 makalenin 6 tanesinin doğrudan film festivallerini incelediği belirtilmiştir. Grunwell \& Ha (2008) film festivallerinin başarısı üzerine ampirik bir çalışma gerçekleştirirken De valck, (2006; 2007; 2008) film festivalleri üzerine tez çalışması, kitap ve makale, Ruling \& Pedersen (2008) örgütsel çalışmalar perspektifinden film festivali araştırması ve Odabaşı (2016) Türkiye'deki Gezici Film Festivali odağında bir çalıșma gerçekleștirmiştir. Yine yabancı alan yazında yer alan Antolí-Calleja ve diğ. (2016), Wong (2011) ve Stringer (2001) tarafından doğrudan film festivallerini ele alan akademik çalışmalar da mevcuttur.

Ulusal alan yazın incelendiğinde ise yine film festivalleri ile ilgili kapsamlı çalışmaların yapıldığı görülmektedir. Seçen (2019), "Altın Portakal Film Festivali: Ödüllü Filmlerde Sinematografik Özellikler ve Toplumsal Cinsiyet Temsillerinin Değişimi” adlı çalışmasında Antalya Altın Portakal Film Festivali'nde En İyi Film Ödülü’nü alan filmlerdeki erkek ve kadın temsilleri üzerine incelemede bulunmuştur. Elmas (2019) film festivallerinin kısa film yapımına etkisi, Akgül (2019) feminist kuram perspektifinden kadın filmi olgusu, Bikiç Çakar (2018) Türkiye»de belgesel film festivallerinde film seçimlerini belirleyen etkenleri, Türten (2018) devletin kültürel ideolojik aygıtı olarak TRT Belgesel Ödülleri'ni Althusserci açıdan bir yaklaşımla ele alırken, Öcal (2013) ise Film festivalleri ve anlatı çalışmalarını gerçekleştirmiştir. Bunun yanı sıra Aytaç (2018), "Film Festivallerinde Belgeseller ve Sansür: Yeryüzü Askın Yüzü Oluncaya Dek ve Bakur» adlı çalışmasında belgeseller örneklemi üzerinden film festivallerinde belgesellere yönelik yapılan sansür uygulamalarını, Yetkiner (2017) ise "Türkiye'de Film Festivallerinin Dönüşen Yapısı" adlı çalışmasında Türkiye'deki film festivallerinde yaşanan maddi sıkıntıları, film 
festivallerinin aldığı maddi destekleri, içeriklerini, isleyişlerini incelemiştir. Uğurlu \& Uğurlu (2011), "Uluslararası Eskişehir Film Festivali İzleyici Araştırması" adlı çalışmada izleyicilerin film festivalleri sırasında filmleri nasıl tercih ettikleri konusunda incelemede bulunmuştur. Uğurlu \& Aşkan (2018) ise “Türkiye'deki Uluslararası Film Festivalleri ve Uluslararası Eskișehir Film festivali İzleyici Araștırmaları" adlı çalışmasında Uluslararası Eskișehir Film festivali izleyici profilini tanımlamıștır. Ulusal ve Uluslararası alan yazın incelendiğinde film festivallerinin köklü tarihi ve çeşitliliğini ele alan ve çeşitli disiplinlerle ortak paydada buluşan birçok çalışmanın yapıldığı görülmektedir. Bu çalışma kapsamında turizm disipliniyle ele alınacak film festivalleri düzenlendikleri destinasyonlar için ayrıcalıklı ekonomik ve kültürel kazanım olușturması kapsamından ele alınmıștır.

\section{Film Festivallerinin Destinasyona Etkileri}

Geniş kapsamda turizm destinasyonu, sahip olduğu çeşitli turizm kaynakları ile turistleri çeken ve yoğun olarak turist ziyaretine ev sahipliği yapan pek çok kurum ve kuruluşun sağladığı doğrudan veya dolaylı turizm hizmetlerinin bütününden oluşan karmaşık bir ürün olarak tanımlanmaktadır (Özdemir, 2007). Dar kapsamda ise turist toplumunun yerel toplum içinde bulunduğu coğrafi bir yer ya da bölge olarak tanımlanmaktadır (Tinsley \& Lynch, 2001). Bir bölgenin turistik destinasyon olabilmesi ve turizm açısından gelişebilmesi için sahip olması gereken birtakım özellikleri vardır. Bu özellikler, çekicilikler başta olmak üzere, imaj, ulaşım, konaklama, yeme-içme, festivaller, park, müze, ören yeri ve benzeri eğlence-dinlence imkânlarının varlığı gibi bir takım ürün ve hizmetlerin karıșımı olarak ifade edilebilir (İlban, 2007, s. 6-7). İlban'ın ifade ettiği bir destinasyonun sahip olması gereken özellikler aynı zamanda destinasyonun pazarlanmasında ve tanınırlığının sağlanmasında önemli bir yere sahiptir.

$\mathrm{Bu}$ hususta film festivalleri destinasyonun pazarlanmasinda ve yerel ekonominin güçlendirilmesinde başat rollerden birine sahiptir. Çünkü film festivali organizasyonları festivale katılım maksadıyla yeni turizm talebi oluşmasını sağlamakla beraber turizm faaliyetleri için destinasyona gelmiş olan ziyaretçilere destinasyonun rutin seyri dışında etkinlik ortaya koymaktadır. Bir destinasyonun tarihi ve kültürünün o destinasyonun en önemli kaynaklarından biri olması ve film festivallerinin yerel kültürel mirasın tanıtılması, korunması, bölgeye ait örf, adetlerin hatırlatılması, var olan kültürün tanıtılıp evrensel düzeyde görünür hale gelmesi ve gelecek nesillere aktarılmasında bir araç işlevi görmesi, film festivalleri ve turizmin ilişkisini gözler önüne sermektedir. Destinasyonların sahip olduğu tarihi ve kültürel kaynakların film festivalleri aracılığıyla bir turistik ürün olarak ziyaretçilere sunulması veya düzenlenen film festivallerine katılım sağlayan ziyaretçilerin ana motivasyon kaynağının başka kültürlerle bütünleşme isteği ise film festivali organizasyonlarının kültür turizmi kapsamında değerlendirilmesinin yanlıș olmayacağını desteklemektedir. Kültür turizmi, ziyaretçinin temel motivasyonunun bir turizm destinasyonundaki somut ve somut olmayan kültürel cazibe merkezlerini veya ürünlerini öğrenmek, keşfetmek, deneyimlemek ve tüketmek olduğu bir turizm aktivitesi türüdür (UNWTO, 2017, s. 18). Bu kapsamda kültür turizmi kapsamında destekleyici veya olay çekiciliğine sahip film festivalleri de önemli bir turizm olayıdır.

Film festivalleri, destinasyonun var olan otantik kültürüne bir bakıș vaat ederek bölgeleri durağan çekim merkezi konumundan güçlü turizm potansiyeline sahip bir varış noktası haline getirme potansiyeline sahiptir (Lee, Lee, Lee, \& Babin, 2004; Rivera, Hara, \& Kock, 2008; Kim, Prideaux, \& Chon, 2010; Şengül \& Genç, 2016). Bunun yanı sıra film festivalleri bölgenin tanıtımında, markalașmasında, imajının artmasında ve kent kimliği kazanmasında yoğun bir şekilde etki göstermekte (Chalip \& Costa, 2005; Lee \& Arcodia, 
2011; Crockett \& Wood, 1999) mevcut destinasyona sosyo-kültürel (Fredline, Jago, \& Deery, 2003; Getz, 2008; Gürsoy, Kim, \& Uysal, 2004; Mair \& Whitford, 2013; Pasanen, Taskinen, \& Mikkonen, 2009) ve ekonomik (Dwyer, Forsyth, \& Spurr, 2005; Kim, Scott, Thigpen, \& Kim, 1998; Thrane, 2002) düzeyde katkılar sağlamaktadır. Aşağıdaki bölümde film festivallerinin destinasyon üzerindeki ekonomik, sosyo-kültürel, imaj ve bölge tanıtımına yönelik etkileri irdelenmektedir.

\section{Film Festivallerinin Ekonomik Etkileri}

Alan yazında festivaller ve turizm ile ilgili araştırmaların büyük bir kısmının ağırlıklı olarak festivallerin ekonomik etkileri üzerine odaklandığı görülmektedir (Organ, KoenigLewis, Palmer, \& Probert, 2015). Festivallerin destinasyona sağlayacağı en belirgin özellik kısa süreli ziyaretçi sayısındaki artış olacaktır (Devine \& Devine, 2017). Özellikle düşük sezon olarak tanımlanan dönemlerde düzenlenen festival sayıları ile bölgeye gelen ziyaretçi sayısında doğru orantı bulunmaktadır (Jackson, 2008). 1960 yılından beri düzenli olarak Ekim ayında Avusturya'nın başkenti Viyana'da düzenlenen Viyana Uluslararası Film Festivali (Viennale), her yıl ortalama 75.000 ziyaretçi çekmektedir. Festival kapsamında ulusal ve uluslararası pek çok film galası, belgesel film ve kısa film gösterimleri yapılmasının yanı sıra önemli sinema sanatçılar ile ziyaretçilerin buluşabildiği toplantılar düzenlenmesi turizm sezonu dışında kalan dönemde destinasyonda haraketlilik sağlamaktadır (Vienna International Film Festival, 2020). Bu tür etkinliklerin festivalin düzenlendiği destinasyonun ekonomisi üzerinde dolaylı gelir etkisi yaratması kaçınılmazdır. Benzer şekilde 2015 yılında yaklaşık 20 milyon Euro bütçe ile düzenlenen Cannes Film Festivali, bütçesini 4'e katlayarak kendisine ve Cannes'e yaklaşık 72 milyon Euro'luk gelir kazandırmıştır. İlgili gelirin temel kaynağını festival zamanı șehre gelen turistler oluşturmaktadır.

Resmi rakamlara göre, 2015 yılında festival süresince, Cannes'ın bulunduğu ProvenceAlpes Cote d'Azur bölgesinde konaklayan 84 bin 400 ziyaretçinin toplamda 65,3 milyon Euro harcama yaptığı tespit edilmiștir. Normalde 70 bin olan Cannes nüfusu, festivalin düzenlendiği iki haftalık dönemde 3'e katlanarak yaklaşık 200 bine ulaşmaktadır. Aynı zamanda konaklamanın zirveye ulaştığı bu dönemde, festival bölgesi ve çevresinde faaliyet gösteren oteller yıllık gelirlerinin yüzde 15'ini festival döneminde kazanmaktadır (Euromonitor International , 2020). Dianne \& Marion (2002) festivallerin düzenlendikleri bölgedeki otel, restoran, hediyelik eşya, eğlence hizmeti gibi hizmet sektöründen her türlü işletmeye katkı sağladığını ifade ederek bu durumu teyit etmektedir. Festival katılımclarının festival süresince konaklama, yeme içme, ulaşım, alışveriş gibi gereksinimleri için yapmış oldukları kısa dönemli harcamalar, yerel halkın kalkınmasına da olanak sağlamaktır (Özgürel, Alan, \& Bingöl, 2015). Örneğin, Amerika Birleşik Devletleri'nin Utah kentinde düzenlenen Sundance Film Festivali'nin 2017 yılında 151,5 milyon ABD doları ekonomik etki yarattığı bilinmektedir (Sundance Institute, 2017).

Yukardaki bilgilerle birlikte, Kızılırmak (2006) festival ziyaretçilerinin, festival süresince destinasyonda yüksek harcama eğiliminde olduklarına, bölgeye ve yerel halka ekonomik katkı sağladıklarına dikkat çekerken, Özkan ve dĭg., (2015) ise festivalleri, yerel işletmelerin dışa açılması, yeteneklerini sergilemesi ve kazanç sağlaması açısından önemli görmektedir. Aynı şekilde Chang (2006) festivallerin yerel ekonominin güçlenmesinde önemli bir etken olduğunu belirtirken, Dredge \& Whitford (2011) festivallerin özellikle gelişmemiş kırsal bölgelerde ekonomik büyüme ve yerel kalkınma için araç olarak kullanıldığını ifade etmiştir. Litvin \& Fetter (2006) çalışmasında yerel konaklama işletmeleri için talep yaratma gücüne sahip festivallerin destinasyonlara turist çekmek 
için kullanılabilecek en temel unsurlardan biri olduğunu tespit etmişlerdir. Yukarıda belirtmiş olduğumuz ifadelerden özetle düzenlenen festivaller; destinasyondaki turizm gelişimine, ekonomik büyüme ve kalkınmaya, yerel esnafa ve yerel halka önemli düzeyde katkı sağlamaktadır.

\section{Film Festivallerinin Sosyo-Kültürel Etkileri}

Yönetmenlerin dünya görüşlerini, duygularını, gördüklerini, yaşadıklarını izleyiciye aktarma çabasında bulunduğu filmlerin, izleyici ile buluşmasını sağlayan film festivallerinin, toplumsal ve sosyo-kültürel işlevlere sahip aracılar konumunda olması kaçınılmaz bir durumdur. Dünyanın farklı kültürlerine ait çok sayıda filmi seyirciyle buluştururken aynı zamanda düzenlendikleri destinasyonlar için ayrıcalıklı kültürel değer ile kazanımlar sağlayan ve küresel ağın parçası olan film festivalleri, fikrin oluşmasından izleyiciye sunulmasına kadar geçen süreçte kültürel değerlerin ortaya konulduğu bir zincir olarak tabir edilen film endüstrisinin de birer bileşeni konumundadır (Stringer, 2001). Festivaller sahip oldukları bu konumla birlikte güçlü sosyal bağlar kurma, birlik duygusu yaratma, toplumsal düzeyde kaynaşma ve kültürel bütünleşmeyi sağlama konularında düzenlendikleri bölgelere sosyal ve kültürel açıdan önemli katkılar sağlamaktadır (Derrett, 2000; Small, Edwards, \& Sheridan, 2005; Gürsoy, Kim, \& Uysal, 2004; Shyllon, 2007). Bu noktada film festivalleri için; yerel halk, yönetmenler, film yapımcıları, aktörler ve sanatseverler arasındaki etkileşimler için firsat yaratan sosyal, kültürel ve sanatsal yönü ağır basan etkinliklerdir demek yanlış olmayacaktır.

Film festivalleri, düzenlendikleri destinasyona sadece izleyici çekip ekonomik hareketlilik yaratmakla veya bölgenin küresel medyadaki görünürlüğünü arttırmakla kalmamakta, aynı zamanda kitlelere büyük etkinlikleri yapma becerisine sahip olunduğunu ve bölgenin kültürel olarak canlı olduğunu göstermektedir (Ooi \& Pedersen, 2010). Her gün dünyanın dört bir yanından gelen yeni göçmenleri ağırlayan ve yaklaşık 2,8 milyonluk nüfusu ile 200'den fazla dil konuşulan Toronto, dünyanın kültürel açıdan en çeşitli şehirlerinden biridir. Zira, Toronto Uluslararası Film Festivali (TIFF), bu dinamik topluluğu, misyonunu "insanların dünyayı film yoluyla görme biçimlerini dönüştürmek" olarak tayin ederek, hareket kabiliyeti veya sosyoekonomik durumunun ortak deneyimi yoluyla kitlelere kendilerini ve kültürel bakış açılarını ifade etmeleri için ilham vermeyi hedefleyen kültürel bir etkinlik içinde yönetme eğilimindedir (Toronto International Film Festival , 2020). Belirli bir kültürel ideoloji kapsamında ele alınan film festivalleri, yerel kültürel mirasın tanıtımı, korunması, bölgeye ait örf, adetlerin hatırlatılması, var olan kültürün tanıtılıp evrensel düzeyde görünür hale gelmesi ve gelecek nesillere aktarılmasında bir araç işlevi görmektedir (Türten, 2018; Bikiç Çakar, 2018).

Benzer şekilde alan yazında festivallerin kültürel işlevleri üzerine yapılan çalışmalar incelendiğinde Derrett (2000) toplumun kültürel gelişiminde festivallerin etkin bir rol olduğunu belirtirken, Shyllon (2007) geleneksel değer ve kültürün yaşatılmasında festivallerin bir model olduğu üzerinde durduğu görülmektedir. Mair \& Whitford (2013) ve Huang ve diğ. (2010) festivallerin toplumsal aidiyet ve kimlik duygusunu arattığını, Gül ve diğ. (2013) ise toplumsal kaynaşma yaratarak yerel halk ve katılımcı nezdinde sosyal kazanımları arttırdığını belirtmektedir. Giritoğlu ve diğ. (2015) turizm ve festival etkinlikleri üzerine yaptığı çalışmada, festivallerin turist ile yerel halk arasında var olan etkileşimi en üst seviyeye çıkararak, yerel halkın turizme bakış açısı üzerinde olumlu etki yarattığını ve yerel halk üzerinde sosyal gelişmeler meydana getirmesine olanak sağladığını vurgulamaktadır. Özetle film festivalleri için yerel kültürel mirasın korunmasında, tanıtılmasinda, unutulmaya yüz tutmuş örf ve adetlerin yeniden 
canlandırılmasında, kültürün gelecek nesillere ulaştırılmasında, var olan değerlerle gurur duyularak toplumsal özgüvenin artırılmasında, yerel halkın yaşam kalitesinin yükseltilmesinde bir araç olduğu söylenebilir.

\section{Film Festivallerinin İmaj ve Bölge Tanıtımına Yönelik Etkileri}

Kültürler arası karşılıklı anlayışı geliştirme, film yapımcısı, dağıtıcısı, yönetmen ve seyircisini ortak paydada bulușturma, farklı film arayışında bulunan bireylerin isteklerini tatmin etme ve sinema kültürünü yaygınlaştırma işlevlerinin yanı sıra film festivalleri, festival dönemi boyunca destinasyonda birçok katılımcı, yönetmen, aktör ve aktriste ev sahipliği yapması dolayısıyla destinasyonun en önemli tanıtım ve turizm unsurlarından biri konumundadır. Bölge imajını olușturmak, tanıtımını yapmak, geliștirmek ve markalaşmak için önemli bir etken olan film festivalleri, destinasyonlar tarafından halkla ilişkiler aracı olarak kullanılarak düzenlenen destinasyonun farkındalı̆̆ı, çekiciliği ve karlılığını arttırma potansiyeline sahiptir (Getz, 2008). Film festivalleri düzenlendikleri şehirlerle özdeşleşerek o şehrin bir marka haline gelmesine ve turistik bir destinasyon olmasına olanak sağlamaktadır. Bu duruma verilebilecek en önemli örnek, 1939 yılında düzenlenmeye başlayan, Avrupa'daki en önemli ilk üç film festivalinden biri olarak gösterilen ve yılda ortalama 20 filmin yarıștığı dünyanın en eski, en etkili ve en prestijli film festivali "Cannes Film Festivali”dir (Uğurlu \& Uğurlu, 2011). Fransa'nın güneyindeki Fransız Rivierası'nın balıkçı kasabası olarak bilinen Cannes, 1952 yılından beri düzenli olarak Mayıs ayında gerçekleştirilen film festivali sayesinde Avrupa'nın popüler ve ciddi turist çeken turistik destinasyonu olmakla beraber Fransa'nın varlıklı ailelerinin yaşadığı lüks Akdeniz kasabası haline gelmiştir. Birleşmiş Milletler'e bağlı Dünya Turizm Örgütü (UNWTO) raporuna göre, 2019 yılında Fransa en çok turist çeken ülkeler sıralamasında 90. 2 milyon turist ile birinci sırada yer almıştır (UNWTO, 2020).

Diğer bir yandan 1951 yılında düzenlenmeye başlayan ve "Berlinale" olarak bilinen her yıl Şubat ayında gerçekleştirilen "Berlin Uluslararası Film Festivali" de Berlin şehri ile birlikte anılmaktadır. Öyle ki festival kapsamında verilen Altın ve Gümüş Ayı Ödülleri’nin Berlin şehrinin sembolü olması, festivalin destinasyon markalaşmasında, imaj ve tanıtımında önemli bir gösterge olduğunu teyit etmektedir. Bunun yanı sıra 1932 yılından itibaren her yıl Ağustos ayının son haftası ile Eylül aynın ilk haftası arasında düzenlenen ve dünyanın en eski film festivali olan "Venedik Film Festivali" de Avusturya'nın Viyana kentiyle özdeşleşmiştir. Bu durum beraberinde, her yll festival süresince Viyana'da turist geceleme sayısının önceki aylara nazaran ortalama \%3,8'lik artış göstermesi sonucunu getirmiștir (Statistik Austria, 2020). Ayrıca "Sundance Film Festivali" Amerika'nın Utah şehrinde 1978 yılından beri, "Toronto Uluslararası Film Festivali" 1976 yılından beri ve "Newyork Uluslararası Film Festivali" 1963 yılından beri düzenli olarak yapılmakta ve festivaller kapsamında gerçekleştirilen özel etkinliklerle birlikte paneller, atölyeler gibi çeşitli faaliyetler, festival destinasyonlarında ziyaretçi sayısının artmasına etki etmektedir.

Türkiye özelinde bakıldığında ise Adana'da düzenlenen "Altın Koza Film Festivali", "Antalya Altın Portakal Film Festivali", "Ankara Uluslararası Film Festivali", "Uluslararası İstanbul Film Festivali" düzenledikleri bölgelerle özdeşleşen ve destinasyonların bir marka haline gelmesini tetikleyen önemli etkinliklerdir. Zira, Altın Koza Film Festivali ve Antalya Altın Portakal Film festivalinin logolarında şehrin sembollerinin bulunması bu festivallerin bölgeyle özdeşleştiği ve bölge tanıtımını desteklediğini kanıtlar niteliktedir. Bir destinasyonda düzenlenen film festivalleri ile medyanın ilgisi çekilerek ve güçlü imaj yaratılarak destinasyon markalaşmasına ve tanıtımına katkı sağlanmaktadır. 


\section{Araştırmanın Amacı ve Önemi}

$\mathrm{Bu}$ çalışmada belgesel film yönetmenlerin bakış açısıyla turizm kapsamında destekleyici bir ürün olarak ele alınan film festivallerinin düzenlendiği bölgeye ve bölge turizmine katkılarının tespit edilmesi amaçlanmaktadır. Düzenlendikleri destinasyonlar için ayrıcalıklı ekonomik ve kültürel kazanım oluşturan film festivalleri, film yapımcısı ve dağıtıcısını ortak paydada buluşturma, farklı film arayışında bulunan bireylerin isteklerini tatmin etme ve sinema kültürünü yaygınlaştırma işlevlerinin yanı sıra, festival dönemi boyunca destinasyonda birçok katılımcl, yönetmen, aktör ve aktriste ev sahipliği yapması dolayısıyla destinasyonun en önemli tanıtım ve turizm unsurlarından biri konumunda olması nedeni ile araştırma kapsamında ele alınmıştır. Bu çalışma diğer araştırmalardan farklı olarak bir çeşit turizm etkinliği olan film festivallerinin en önemli unsurlarından olan yönetmenlerin festivallerin düzenlenme amaçlarından biri olan turizm ayağı konusundaki görüşlerini incelemektedir.

Çalışma kapsamında belgesel film yönetmenlerinin seçilmesinin nedenlerinde ilki belgesel film yönetmenlerinin yapmış oldukları iş gereği eserleri ile milyonlarca insanı etkileyebilme gücüne sahip olmaları ve aynı zamanda toplumda kimi zaman eşik bekçisi kimi zaman ise kanaat önderi görevi üstlenmeleridir. Diğer bir neden ise Türk belgesel tarihinin önemli isimleri arasında olan Suha Arın'ın Safranbolu"nun, UNESCO tarafından Dünya Miras Listesi"ne alınma sürecinde 1976 yılında hazırladığı Altın Portakal Ödüllü "Safranbolu'da Zaman" belgesel filmi, Safranbolu'nun bilinirliğini arttırması ve önemli bir kültürel turizm destinasyonu olmasını sağlamasıdır (Akbulut, 2020). Bu hususta belgesel film yönetmenlerinin film festivalleri ve düzenlendikleri bölgenin turizm gelişimi hakkındaki görüşleri, film festivallerinin amaçları doğrultusunda yönetilebilmesi ve aynı zamanda düzenlendikleri bölgenin turizm gelişiminin olumlu yönde evrilmesi hususunda önemli görülmüş ve çalışma belgesel film yönetmenleri üzerinde yürütülmüştür. Alan yazında film festivalleri ile ilgili çeşitli konularda çalışmaların yer aldığı bilinmekte ancak bu çalışmaların ağırlıklı olarak festivallerin sanatsal ve teknik yönü üzerine odaklandığı görülmektedir (Seçen, 2019; Elmas, 2019; Akgül, 2019). Ayrıca alan yazında gastronomi, kültür gibi farklı türlerdeki festivaller ve turizm ilişkisine dair araştırmaların olduğu bilinmekle beraber film festivalleri ile turizm ilişkisinin değerlendirildiği çalışmalara rastlanılmamış olması alan yazındaki boşluğu doldurması açısından bu çalışmayı önemli kılmaktadır.

\section{Araştırma Yöntemi}

Betimleyici ve açıklayıcı bir araştırma olarak ele alınan bu çalışmada nitel araştırma yöntemi benimsenmiş olup veriler görüşme (mülakat) tekniği ile toplanmıştır. Araştırmada kullanılan yarı yapılandırılmış görüşme formu, literatür taramasına ve alanda uzmanlığa sahip akademisyenlerin görüşlerine bağlı kalınarak belirlenmiş açık uçlu 8 sorudan oluşmaktadır. Araştırma kapsamında yarı yapılandırılmış görüşme formu kullanılmasının sebebi; araştırmanın amacına uygun olarak önceden hazırlanmış ve katılımcıları kesin hatlarla sınırlandırmayan, aynı zamanda hayal gücünü kullandırarak kendi cümleleriyle ifade etmeye yönelten açık uçlu sorular sorulması ve ayrıntılı bilgi alma fırsatı sunmasıdır (Yıldırım \& Şimşek, 2016). Böylece yönetmenlerin film festivalleri ile düzenlendikleri bölge ve bölge turizmine sağladığı katkılar hakkındaki görüşlerine ilişkin ayrıntılı bilgiye ulaşılabileceği düşünülmüștür. Araştırmanın evrenini Türkiye'de film festivallerine davetli olarak katılan belgesel film yönetmenleri oluşturmaktadır. Araştırmanın örneklemi ise kolayda örneklem yöntemi ile Türkiye'de ikamet ettiği şehrin dışında en az 5 film festivaline davet edilmiş ve festival yönetimi tarafından ağırlanmış 
belgesel film yönetmenleri arasından seçilmiştir. Benzer cevapların alınmaya başlanması dolayısıyla örneklem ilgili ön koşula uyan 12 belgesel film yönetmeni ile sınırlandırılmıştır. Görüşmeler 1-30 Mayıs 2020 tarihleri arasında gerçekleştirilmiştir.

Araştırmada nitel araştırma yöntemlerinden içerik analizi yöntemi kullanılmıştır. İçerik analizinde temel amaç, toplanan verileri açıklayabilecek kavramlara ve ilişkilere ulaşmaktır. İçerik analizinde temelde yapılan işlem, birbirine benzeyen verileri belirli kavramlar ve temalar çerçevesinde bir araya getirmek ve bunları okuyucunun anlayabileceği bir biçimde organize ederek yorumlamaktır (Yıldırım \& Şimşek, 2016). Görüşme (mülakat) yöntemi ile elde edilen veriler, veri analizi ile betimlenmiş ve yorumlanmıştır.

Araştırmada, katılımcı yorumları literatür taramasına dayanan bir kodlama şeması kapsamında koda dönüştürülerek açık kodlama yapılmıştır. Araştırmanın geçerliliği meslektaş teyidi yöntemi ile gerçekleştirilmiş olup, yapılan kodlamalar alanında uzman akademisyen tarafından doğrulanmıștır.

Araştırmanın güvenilirliğini belirlemek için ise yapılan kodlamalar bir turizm alan uzmanı akademisyen tarafından da incelenerek ayrı kodlama yapılmış ve yapılan kodlamalar karşılaştırılarak tutarlılık oranının belirlenmesi için elde edilen temalar MAXQDA 2020 nitel veri analiz programı ile güvenilirlik testlerinden biri olan Kappa analizine tabi tutulmuştur (Viera \& Garrett, 2005). Cohen's Kappa kat sayısı .813 ile .819 değer aralığında tespit edilmiştir. Landis ve Koch (1977)'ye göre Cohen's Kappa uyum değerinin 0.81 ile 1.00 arasında olması iyi/çok iyi düzeyde bir uyumun olduğunu göstermektedir. Dolayısı ile çalışmada kodlayıcılar arasında iyi düzeyde bir uyum olduğu ve kodlama anahtarının güvenilir olduğu söylenebilmektedir. Araştırma kapsamında elde edilen veriler bilgisayar destekli nitel veri analizi programı (computer assisted qualitative data analysis software / CAQDAS) olan lisanslı MAXQDA 2020 ile analiz edilmiştir. MAXQDA nitel analiz programı araştırmacıya analiz sürecinin daha sistematik ve açık yapılması hususunda katkı sağlamakla beraber yapılan kodlamaları kontrol ve gerektiği taktirde düzenleme olanağı tanımaktadır.

Analiz kapsamında görüşme soruları ile elde edilen cümle ve paragraflar genel bir çerçeve içerisinde alan yazından faydalanılarak kodlanmış ve kavramsallaştırılmıș, ardından elde edilen veriler tematik kodlamaya uygun düzenlenmiş ve tanımlanmıştır. Ortaya çıkan sonuçlar bulgular kısmında bir kodun alt kodları ile birlikte katılımcı ifade sayılarına göre sunulmuştur. Bu çalışma bazı sınırlılıklara sahiptir. Yapılan bu çalışmanın ilk sınırlılığını sadece 12 adet ve en az 5 farklı şehirde film festivaline katılan yönetmenlerin görüşlerini içeriyor olmasıdır. Bir diğer sınırılık ise çalışma sadece ekonomik, sosyo-kültürel etkiler ve bölgenin tanıtım ve imajını inceliyor olmasıdır. Çalışmada yönetmenlerin bakış açısıyla film festivallerinin düzenlendiği bölgeye ve bölge turizmine katkılarının tespit edilmesine yönelik aşağıdaki araştırma sorularına cevap aranmıştır.

\section{Araştırma Soruları:}

1. Bir şehirde film festivallerinin düzenlenmesi o şehirdeki turistik işletmeler (otel, pansiyon restoran, müze ve ören yerleri, hediyelik eşya dükkanları gibi) için ekonomik katkı sağlamakta mıdır?

2. Bir şehirde film festivallerinin düzenlenmesi o şehirde ikamet eden yerel halk ile festival katılımcıları arasında sosyal ve kültürel entegrasyon sağlayarak, sosyo-kültürel katkı sağlamakta mıdır? 
3. Bir şehirde film festivallerinin düzenlenmesi o şehrin tanınması ve bir marka şehir olması konusunda etkin rolü var mıdır?

\section{Araştırmanın Çalışma Grubu}

Katılımcıların tamamı Türkiye'de ikamet ettiği şehrin dışında en az 5 film festivaline davet edilmiş ve festival yönetimi tarafından ağırlanmış belgesel film yönetmenlerinden oluşmaktadır. Görüşme katılımcılarının özelliklerine ilişkin genel bilgiler Tablo 1'de verilmiştir.

Tablo 2. Katılımcılara Ait Genel Bilgiler

\begin{tabular}{|l|l|l|l|c|c|c|}
\hline $\begin{array}{l}\text { Katılımc } \\
\text { Kodu }\end{array}$ & Cinsiyet & Yaş & Eğitim Durumu & $\begin{array}{c}\text { Meslekteki } \\
\text { Deneyim Süresi }\end{array}$ & $\begin{array}{c}\text { Film Festivali Amacıyla } \\
\text { Gittiği Şehir Sayısı }\end{array}$ & $\begin{array}{c}\text { Katıldığı Film } \\
\text { Festivali Sayısı }\end{array}$ \\
\hline K1 & Erkek & 24 & Lisans & 5 & 8 & 15 \\
\hline K2 & Erkek & 29 & Doktora & 9 & 13 & 30 \\
\hline K3 & Erkek & 25 & Lisans & 3 & 7 & 8 \\
\hline K4 & Erkek & 32 & Lisans & 10 & 6 & 10 \\
\hline K5 & Erkek & 30 & Doktora & 13 & 20 & 25 \\
\hline K6 & Erkek & 22 & Lisans & 4 & 7 & 50 \\
\hline K7 & Erkek & 22 & Lisans & 4 & 5 & 5 \\
\hline K8 & Erkek & 26 & Yüksek Lisans & 5 & 11 & 11 \\
\hline K9 & Erkek & 30 & Yüksek Lisans & 10 & 12 & 20 \\
\hline K10 & Erkek & 29 & Lisans & 11 & 13 & 12 \\
\hline K11 & Kadın & 48 & Doktora & 28 & 30 & 50 \\
\hline K12 & Kadın & 33 & Doktora & 10 & & 5 \\
\hline
\end{tabular}

Tablo'1 incelendiğinde katılımcların \%83'ü erkek ve \%50'sinin lisans mezunu olduğu tespit edilmiştir. Katılımcıların meslekteki deneyim sürelerinin ortalaması 9 yıl; festivale katılmak amacıyla ziyaret etmiş oldukları şehir sayısı ortalaması 11 ve katıldıkları film festivali sayısı ise ortalama 20 olarak gözlemlenmiştir.

\section{Etik Kurul İzni}

Karabük Üniversitesi Rektörlüğü Sosyal ve Beșeri Bilimler Araștırmaları Etik Kurulu 04/11/2020 tarih ve 2020/12-18 no'lu toplantısında alınan karar çerçevesinde çalışma etik açıdan bir sakınca içermemektedir.

\section{Araștırma Bulguları}

Bulgular kısmında yönetmenlerin, turizm kapsamında destekleyici bir ürün olarak ele alınan film festivallerinin düzenlendiği bölgeye ve bölge turizmine olası katkılarına ilişkin vermiş oldukları cevaplar "ekonomik", "sosyo kültürel" ve "tanıtım ve imaj" olmak üzere üç başlık altında sıralanarak sunulmaktadır.

\section{Ekonomik Katkılara Illişkin Bulgular}

Katılımcıların film festivallerinin düzenlendiği bölgeye ve bölge turizmine ekonomik katkılarına yönelik görüşlerinin kodlu bölüm sayısına göre sınıflandırılması aşağıda sunulmuştur. 


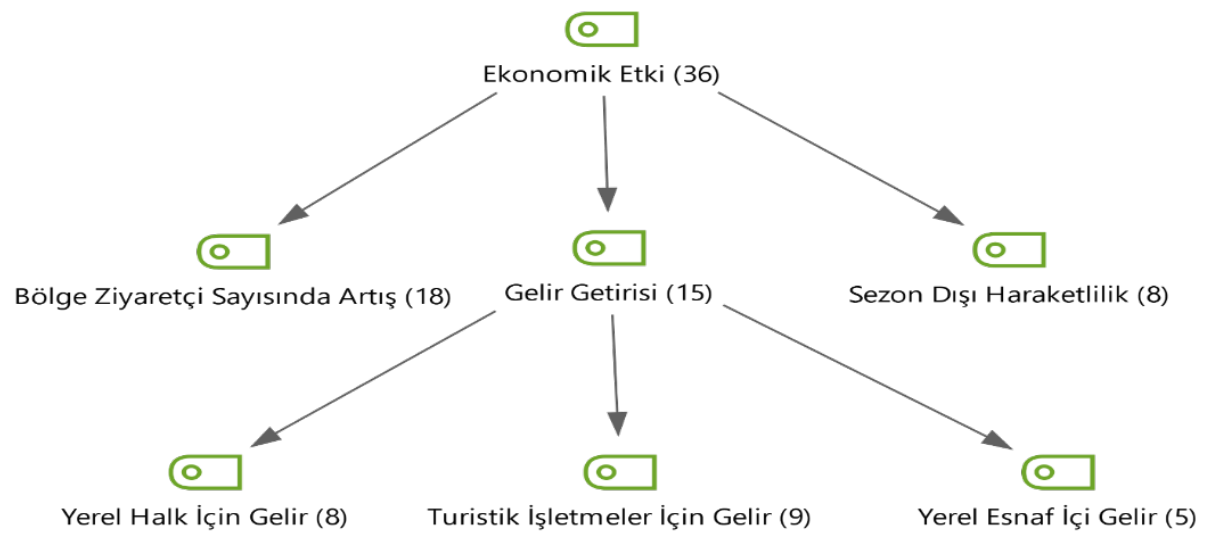

Şekil 1. Katılımcıların film festivallerinin düzenlendiği bölgeye ve bölge turizmine ekonomik katkılarına yönelik görüşlerinin Kodlu Bölüm Sayısına Göre Sınıflandırılması- Kod-Alt kod Modeli

Şekil'1 de belirtildiği gibi katılımcılar 36 ifade ile film festivallerinin düzenlendiği bölge ve bölge turizmine var olan olası ekonomik etkilerinden bahsetmektedir. Katılımcıların ifadeleri film festivallerinin "bölgede sezon dışı haraketlilik, gelir getirisi ve bölge ziyaretçi sayısında artış yaratması" olmak üzere üç temaya ayrılmıştır. Bu ifadelerden 8'i film festivallerinin düzenlendiği bölgeye sezon dışı haraketlilik kazandırdığı, 18'i film festivalinin düzenlendiği bölgenin ziyaretçi sayısını arttırdığını, 15'i ise film festivallerinin düzenlendikleri bölgeye gelir imkânı tanıdığını açıklamaya yöneliktir. Gelir getirisi teması ise katılımcıların görüşleri doğrultusunda 5 ifade ile yerel esnafa gelir, 9 ifade ile turistik işletmelere gelir ve 8 ifade ile yerel halk için gelir olmak üzere 3 alt tema șeklinde olduğu belirlenmiștir. Bu sonuçlar ışığında film festivallerinin bölge ve bölge turizmine yönelik ekonomik katkıları 18 katılımcı ifadesi ile bölgede ziyaretçi sayısında artış yaratma üzerine yoğunlaștığı ortaya çıkmaktadır. Katılımcı ifadelerine göre film festivallerinin bölge ve bölge turizmine yönelik ekonomik katkıları en az sezon dışı haraketlilik yaratma (8) şeklinde belirlenmiştir. Așağıda katılımcı bakış açısıyla, film festivallerinin düzenlendikleri bölge ve bölge turizmine olası ekonomik etkilerini ortaya koymak amacıyla bazı yönetmen katılımcıların yorumlarından örneklere yer verilmiştir.

"Genel olarak film festivalleri bir şehrin tanıtılmasında çok önemli bir role sahiptir. Ülkemizde düzenlenen film festivallerinin büyük bir kısmının düzenlendiği şehrin ziyaretçi sayısını arttırdığını buna bağlı olarak da gerek yerel halka gerekte șehir esnafına ekonomik katkı sağladığını söyleyebilirim. Altın Portakal Film festivalini buna örnek olarak verebiliriz" $(K 4, K 12)$.

"Kesinlikle sağlamaktadır. Verilebilecek en önemli örnek ise Cannes film festivalidir. Festival düzenleyicileri turizm açısından șehre katkı sağlamak adına ulusal ve uluslararası boyutta sektörün önde gelen isimlerini ve bunu yanında sinema yıldılarını şehre davet ederek hem profesyonelleri hem de diğer insanları oraya çekmektedir. Sinema yıldızlarını ve yönetmenlerini görmek isteyen binlerce insan festival süresi boyunca Cannes nüfusunu tam üçe katllyor" (K6, K3).

“.... Bölgede yaşayan insanlar festival döneminde gelen ziyaretçilere evlerini ve hatta odalarını kiraya vererek kendilerine gelir sağllyorlar" (K2, K9).

“... Ekonomik katkı sağladığını söyleyebilirim. Festivale davetli olarak katılan yönetmenler ve diğer katılımcılar çeşitli işletmelerde konaklamakta ve özellikle davetli yönetmenlere yöreye özgü restoranlarda yemek verilmektedir. Birçoğu yöreye ait ürünleri satın almaktadır. Bu durum doğal olarak turistik işletme sahiplerine, esnafa ve restoran sahibine ekonomik katkı 
sağlamaktadır" (K5).

"Bunun cevabına evet diyebilirim ve Antalya Altın Film Festivali ve Adana Altın Koza Film Festivali bu hususta başı çeken iki önemli film festivali olabilir. Özellikle düzenlenme tarihi yazın bitişi olmasına rağmen Antalya'da düzenlenen ve her şeyiyle gelenek haline dönmüş olan Antalya Altın Film Festivali düzenlendiği her sene yurt içi ve yurt dışından turist olarak büyük bir ziyaretçi kitlesini kendine çekmeyi başarır. Haliyle festival döneminde çeşitli aktivitelerde bulunup, turistik alışverişlerde bulunurlar. Dolayısıla film festivalleri ziyaretçi sayısını arttırarak şehrin turist sirkülasyonuna katkıda bulunarak ekonomik katkı sağlar" (K6, K11).

"Evet sağlamaktadır. Birçok şehirden hatta birçok ülkeden festivallere katılım sağlanıyor. Böylelikle festivalin bulunduğu şehirdeki oteller ve restoranlar para kazanıyor. Şehir turu olduğunda anı olarak birçok eşya satın alınıyor. Böylelikle festivalden dolayı şehirde ticaret güzel bir şehirde işliyor ve yerel halk, esnaf işletme sahipleri para kazanıyorlar" (K8, K1).

"Kesinlikle yapılan film festivalleri bir şehre ekonomik olarak büyük katkı sağlamaktadır. Sektör profesyonellerinin festivale katılması, farklı şehirlerden ve ülkelerden insanların düzenlenen gösterim ve etkinliklere katılması festivalin düzenlendiği şehirde bir haraketliliğe sebep olmakta aynı zamanda otel, restoran vb. bölge esnafına da katkı sağlamaktadır "(K10).

\section{Sosyo-Kültürel Katkılara İlişkin Bulgular}

Katılımcıların film festivallerinin düzenlendiği bölgeye ve bölge turizmine sosyokültürel katkılarına yönelik görüşlerinin kodlu bölüm sayısına göre sınıflandırılması aşağıda sunulmuştur.

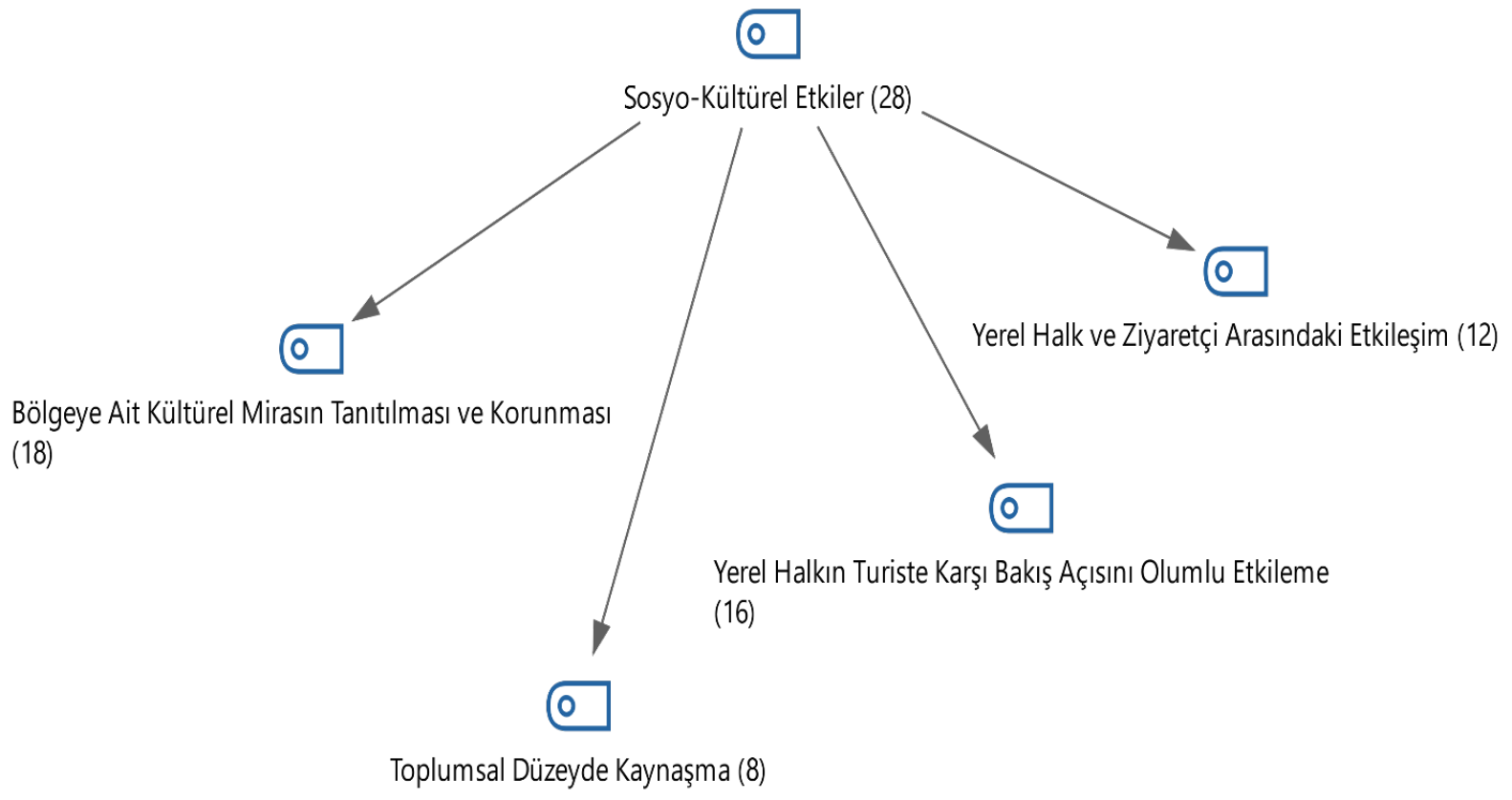

Şekil 2. Katılımcıların film festivallerinin düzenlendiği bölgeye ve bölge turizmine Sosyo-Kültürel katkılarına yönelik görüşlerinin Kodlu Bölüm Sayısına Göre Sınıflandırılması- Kod-Alt kod Modeli

Şekil 2' de belirtildiği gibi katılımcılar 28 ifade ile film festivallerinin düzenlendiği bölge ve bölge turizmine var olan olası sosyo-kültürel etkilerinden bahsetmektedir. Katılımcıların ifadeleri "film festivallerinin bölgeye ait kültürel mirasın tanıtılması ve korunması (18), toplumsal düzeyde kaynaşma (8), yerel halkın turiste karşı bakış açısını olumlu etkileme 
(16), yerel halk ve ziyaretçi arasındaki etkileşim (12)" olmak üzere dört temaya ayrılmıştır. Bu sonuçlar ışığında film festivallerinin bölge ve bölge turizmine yönelik en yoğun sosyokültürel katkıları 18 ifade ile bölgeye ait kültürel mirasın tanıtılması ve korunması üzerine yoğunlaştığı görülmektedir. 16 ifade ile katılımcılar film festivallerinin düzenlendikleri bölge ve bölge turizmine sosyo-kültürel katkısının yerel halkın turiste karşı bakış açısını olumlu etkilediği şeklinde tespit edilmiştir. Film festivallerinin bölge ve bölge turizmine en az sosyo-kültürel katkısı ise katılımcılar tarafından 8 ifade ile toplumsal düzeyde kaynaşma olduğu ortaya çıkarılmıştır. Aşağıda katılımcı bakış açısıyla, film festivallerinin düzenlendikleri bölge ve bölge turizmine olası sosyo-kültürel etkilerini ortaya koymak amacıyla bazı yönetmen katılımcıların yorumlarından örneklere yer verilmiştir.

"Katkı sağladığı aşikardır. Yönetmen olarak katıldığım festivallerde gittiğim yörenin yemekleri ve kültürleriyle karşılaşıyor ve dolayısı ile gerek kültür gerekte yerel halk ile bir etkileşime giriyoruz. Girdiğimiz etkileşimde o yörenin dili, kültürü, yaşayışları, kıyafetleri ve hayatları hakkında fikir sahibi olup o bölgeyi yakından tanıma ve tanıtma firsatı elde ediyoruz" $(K 3, K 9)$.

"Festivallerin düzenlendiği şehirde katılımcılar ile bölge insanı arasında bir bağ kurduğunu söyleyebiliriz. Festival için farklı şehirlerden gelen katılımcılar geldikleri yöreyi tanıma imkânı bularak bölgeye ait kültürel değerler, gelenek, görenek ve örf ve âdet gibi birçok değerini öğreniyor. Böylelikle hem katılımcılar farklı değerler öğrenmiş oluyor hem de yöreye ait değerler tanitıllyor" (K4, K5).

"Evet katkı sağlamaktadır. Festival katılımcıları gezdikleri yörelerde baktıkları, satın aldıkları, yemek yedikleri, çarşı, pazar ve eğlence vb. yerlerinde esnaf ile iletişime geçerek bilgi almakta aynı zamanda şehrin kültürüne ait bilgiler edinmektedirler. Gösterimlerin yapıldı̆̆ı salonlara bölge halkının katılım sağlaması gerek kendi aralarında diyaloglar kurarak etkileşime geçmelerini gerek filmin yönetmeni-ekibi ile sohbet edebilme imkânı elde ederek kaynaşmalarına neden olmaktadır" (K11, K10).

"Festivaller büyük oranda katılımcılar ve yerel halk arasında bir etkileşim sağlamaktadır. Etkileşime geçen yerel halk ve festival katılımcısı kültür ve geleneklerini öğrenerek birbirlerine karşı anlayış ve hoş görü geliştirip ön yargılarından sıyrılacaklardır” (K12, K1).

“Festivaller sayesinde bölgede artan ziyaretçi sayısı yerel halkın kendinden olmayan diğer insanlara karşı ön yargılarını yıkma gibi bir etkisi olabilir. Değişik tarzdaki insanlar ve giyim kuşam tarzı ile yüz yüze kalan yere halk tölere düzeyini arttırabilir" (K3, K6).

\section{İmaj ve Bölge Tanıtımına Yönelik Katkılara İlişkin Bulgular}

Katılımcların film festivallerinin düzenlendiği bölgeye ve bölge turizmine yönelik yarattığı imaj ve tanıtıma yönelik yönelik görüşlerinin kodlu bölüm sayısına göre sinıflandırılması aşağıda sunulmuştur. 


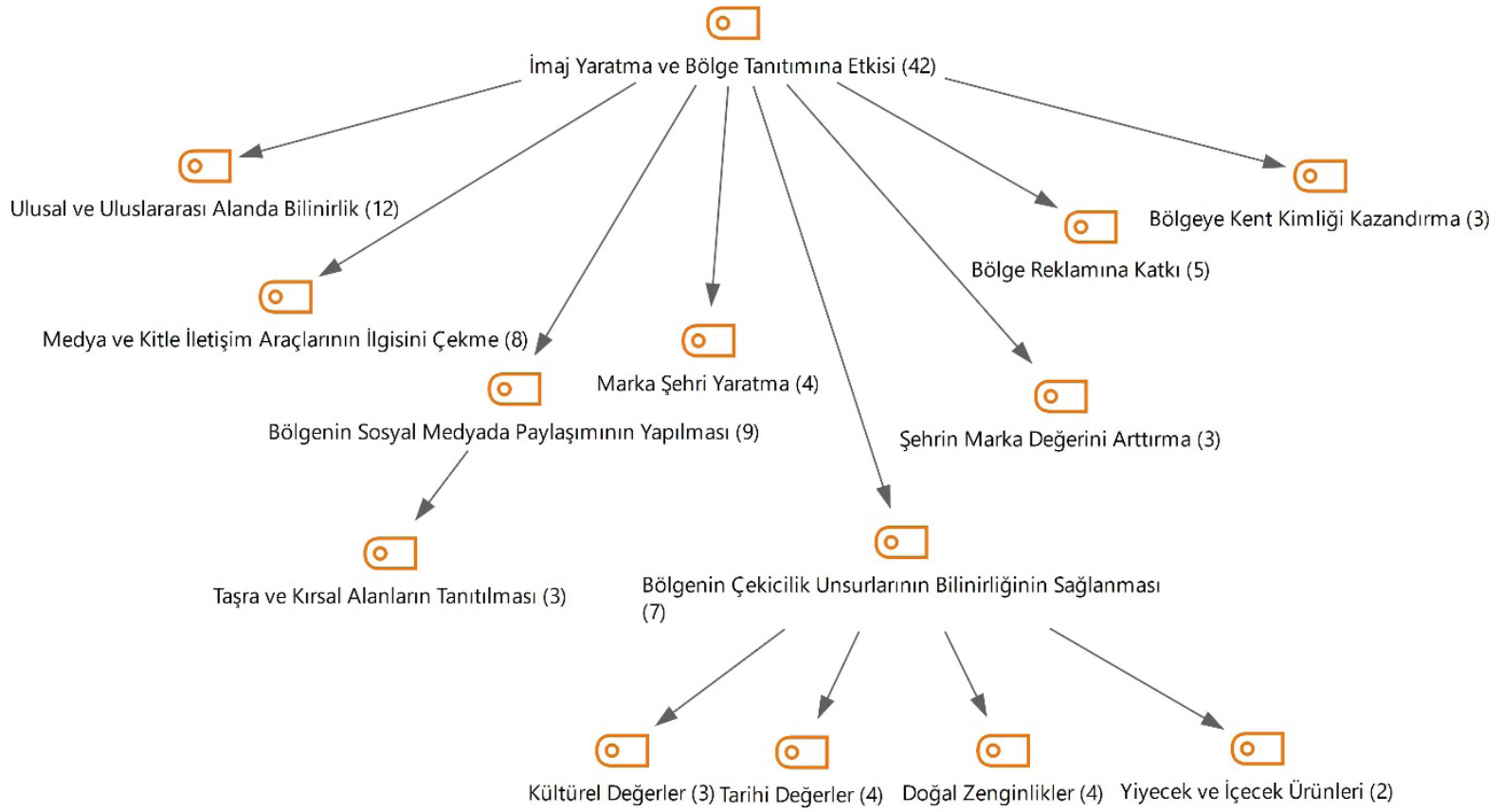

Şekil 3. Katılımclların film festivallerinin düzenlendiği bölgeye ve bölge turizmine yönelik yarattığı İmaj ve Tanıtıma yönelik görüşlerinin Kodlu Bölüm Sayısına Göre Sinıflandırılması- Kod-Alt kod Modeli

Şekil 3’ de belirtildiği gibi katılımcılar 42 ifade ile film festivallerinin düzenlendiği bölge ve bölge turizmine yönelik yarattığı imaj ve tanıtım katkılarından bahsetmektedir. Katılımcıların ifadeleri sekiz temaya ayrılmıştır. Bunlar ifade sıklık sayısının fazlalığına göre; "bölgenin ulusal ve uluslararası alanda bilinirliğinin sağlanması (12), bölgenin sosyal medyada paylaşımının yapılması (9), medya ve kitle iletişim araçlarının ilgisini çekme (8), bölgenin çekicilik unsurlarının bilinirliğinin sağlanması (7), bölge reklamına katkısı (5), marka şehri yaratma (4), şehrin marka değerini arttırma (3) ve bölgeye kent kimliğini kazandırma (3)" şeklinde sıralanmıştır. Bu bilgiler doğrultusunda film festivallerinin düzenlendikleri bölge ve bölge turizmine yönelik yarattığı imaj ve tanıtım katkısının 12 katılımcı ifadesi ile en fazla bölgenin ulusal ve uluslararası alanda bilinirliğini sağlaması olduğu tespit edilirken; en az imaj ve tanıtım katkısı ise katılımcılar tarafından 3 ifade ile şehrin marka değerini arttırması ve bölgeye kent kimliğini kazandırması olduğu tespit edilmiştir. Aşağıda katılımcı bakış açısıyla, film festivallerinin düzenlendikleri bölge ve bölge turizmine yönelik yarattığı imaj ve tanıtım katkılarını ortaya koymak amacıyla bazı yönetmen katılımcıların yorumlarından örneklere yer verilmiștir.

"Festival kapsamında yapılan turistik gezilerin festivalin yapıldı̆̆ı bölgenin reklamının yapılmasında önemli bir unsur olduğunu düşünüyorum. Buna Van ipek yolu film festivalini örnek verebilirim. Van denildiğinde akla genelde kahvaltısl, gölü ve Akdamar kilisesi gelir. Yapılan bu gezide de tam olarak bunların tanıtımı yapıldı... Oralarda birçok kez fotoğraf çekip paylaştık. Ayrıca medyada da haberler yapıldı. Bu durumun şehrin tanıtılması ve reklamının yapılması açısından önem arz ettiğini düşünüyorum” (K11).

"Katıldı̆̆ım film festivallerinde sosyal medyada aktif olarak paylaşım gerçekleştiririm. $\mathrm{Bu}$ paylaşımların hem kendimi tanıtma hem festivalin tanıtımını yapma hem de festivalin düzenlendiği şehrin tanıtımını yapma konusunda önemli olduğunu düşünüyorum" (K2, K12). 
"Davetli olarak gerek yurt dışı gerek yurt içinde çeşitli festivallere katıldım. Hemen hemen hepsinde çeşitli paylaşımlarda bulundum ve takipçilerimin çoğundan böyle bir yerden haberdar değildik şeklinde geri dönüşler aldım. Yapılan paylaşımların şehrin tanıtılmasında ve diğerleri tarafından bilinirliğinin sağlanması açısından katkısı bulunmaktadır (K3, K5).

“.... Festivalin kalitesi ile şehir tanıtımı ve şehrin markalaşması arasında doğru orantı bulunmaktadır. Festivaller katılımcılarına ve onlara yönelik düzenlediği etkinliklere ne kadar önem verirse şehrin markalaşması ve tanıtımı o yönde olur. Bu kapsamda bakıldığı zaman kaliteli film festivallerinin düzenlenmesi hem festivalin popülerliğini ve marka değerini hem de düzenlendiği șehrin popülerliğini ve marka değerini arttıracaktır" (K1).

"Işsin ehli akademisyen, organizatör ve profesyoneller tarafindan oluşan festival komiteleri doğru ve kaliteli film festivallerin ortaya çıkarılması anlamına gelmektedir. İşin uzmanları tarafından doğru organize edilen film festivalleri ise insanlar üzerinde çeşitli hususlarda olumlu etkiler bırakmaktadır. Bu durum șehrin tanıtımından, kendine ait bir kent kimliği oluşturmasından markalaşmasına kadar uzanır. Bir noktadan sonra festivaller şehirlerle anılmaya başliyor (K2, K8).

"Festivaller şehirlerle anılıyor, onlara adeta birer kimlik kazandırıyor. Örneğin Altın portakal deyince aklımıza Antalya, Altın Koza denilince akla Adana gelmesi gibi. Ya da tam tersi Antalya denilince akla sadece deniz kum güneş üçlüsü, Adana deyince sadece kebap gelmeyip iyi organize edilmiş kaliteli film festivallerinin akla gelmesi gibi. Festival iyi organize edildiği taktirde yakın çevremizle paylaşırken bile Festival adından ziyade düzenlendiği şehrin ismini vererek İzmir'deki şu festival ne kadar iyiydi șeklinde paylaşım yapıyoruz, bu da şehirler için doğal reklam oluyor. Tabi iyi organize edilmemiş bir festival ise durum tam tersine dönebiliyor" (K10, K6).

"Festivallerin düzenledikleri şehrin tanıtılmasına katkı sağlamakla beraber bölgenin kültürel ve sanatsal açıdan değerini ön plana çıkarmakta ve şehrin marka değerine ve imajını güçlendirdiğini düşünmekteyim. Örneğin Cannes, Venedik, Berlin, Locarno, Antalya, Adana, Boğaziçi gibi film festivali etkinlikleri düzenlendiği şehrin markalaşmasına ciddi katkı sağlamıştır. Yönetmen, oyuncu ve sinema sektöründen gözde birçok kişinin bu festivallere akın etmesi medyanın gözünü bu şehirlere döndürmektedir. Tabi bu katkı düzeyi festivalin profesyonel şekilde tasarlanıp düzenlenmesi ve tanıtımının iyi yapılmasına ve medya gücünden faydalanmasına bağlı olarak değişmektedir. Prestijli film festivalleri ilgili şehrin dışa açılan yüzüdür ve çok klymetlidir " $(K 5, K 4, K 8, K 9)$.

"Festivallerin özellikle kırsal ve taşra alanların çekicilik unsurlarını görünür kılması, o bölgeyi bilmeyen kitlelere sosyal medya ve yerel medya vasitasıyla tanıtımının yapılmasına katkı sağladığını düşünmekteyim. L̇yi organize dilmiş festival vasıtasıyla bilinirliği az ve daha az gelişmiş bölge medyada duyulup tanınıyor şehir hakkında insanlar bilgi sahibi oluyor hem de sinema sektöründe adını duyuruyor. İşler yolunda ilerlerde festivallerin devamlılığı sağlanırsa bölge kendini marka șehri haline getirme yolunda güzel bir yol kat edebiliyor" (K7).

\section{Sonuç ve Değerlendirme}

Geniş kitlelere ortak bir görüş yaratma işlevine sahip olan film festivalleri, aynı zamanda yaşama da biçim vererek farklı filmleri arayan izleyicilerin, izleyici arayan farklı filmlerin, yönetmenlerin ve oyuncuların bir araya geldiği bir uzam konumundadır. Film festivalleri bu özelliklerin yanı sıra, farklı kültürlerin kaynaştığı, tanıtıldığı aynı zamanda insanların merak ve keşfetme dürtüsünün tatmin etme temelini oluşturan 
turizm faaliyetlerinin temel yapı taşı olan seyahatlerin de tetikleyici bir unsurudur. Hiç kuşkusuz, film festivalleri sinema kültürünü yaygınlaştırma işlevlerinin yanı sıra festival dönemi boyunca destinasyonda birçok katılımcı, yönetmen ve oyuncuya ev sahipliği yapması dolayısıyla destinasyonun en önemli tanıtım ve turizm unsurlarından biri konumundadır. Yönetmenlerin bakış açısıyla turizm kapsamında destekleyici bir ürün olarak ele alınan film festivallerinin düzenlendiği bölgeye ve bölge turizmine katkılarının tespit edilmesi amaçlanan bu çalışma sonuçlarına göre film festivallerinin düzenlendiği bölgeye ekonomik, sosyo-kültürel ve imaj-tanıtımına yönelik üç farklı kapsamda katkı sağladığı tespit edilmiștir. En az 5 farklı șehirde film festivaline katılan belgesel film yönetmenlerinin görüşüne göre, film festivalleri sırasıyla düzenlendiği bölge ve bölge turizmine; bölgedeki ziyaretçi sayısını arttırması, turistik işletmelere, yerel halka, esnafa gelir getirisi sağlaması ve bölgede turistik sezonu uzatması yönüyle ekonomik katkı sağladığı tespit edilmiştir.

Festivallerin destinasyona sağlayacağı en belirgin özellik kısa süreli ziyaretçi sayısındaki artış ve destinasyonun ekonomisi üzerinde dolaylı gelir etkisi yaratmasıdır. Festival katılımcılarının festival süresince konaklama, yeme içme, ulaşım, alışveriş gibi gereksinimleri için yapmış oldukları kısa dönemli harcamaları yerel halkın için gelir olarak yansımaktadır. TIFF grup tarafından 1976 yılından beri Toronto' da düzenlenen yarışmasız bir festival olan Toronto Uluslararası Film Festivali 2018 yılında yaklaşık 10 bin ziyaretçi ile şehre yaklaşık 66 bin \$ getiri sağlamıştır (Toronto International Film Festival , 2020). Çıkan sonuç literatürde bulunan benzer çalışmaların sonuçları ile desteklenmektedir (Kızılırmak, 2006; Özkan, Curkan, \& Sarak, 2015; Chang, 2006; Dredge \& Whitford, 2011). $\mathrm{Bu}$ kapsamda festivallerin düzenlendiği bölgedeki yerel yönetimler, turistik işletme yöneticileri ve yerel halk; festival katılımcılarını ağırlamaya yönelik faaliyetleri kalite, hijyen ve misafirperverlikten ödün vermeden katılımcıların memnuniyet düzeylerini arttırıcı biçimde yürütmeleri festival düzenleyicileri ve katılımcıların sadakat düzeylerini arttıracaktır. Bu durum, film festivalinin düzenlendiği bölge ve bölge turizmine daha fazla ekonomik katkı sağlaması anlamına gelecektir. Araştırmanın diğer sonucu ise film festivalleri sırasıyla; düzenlendiği bölge turizmine ve bölgeye ait kültürel mirasın tanıtılması ve korunması, yerel halkın turiste karşı bakış açısını olumlu etkilemesi, yerel halk ve ziyaretçi arasında etkileşim yaratması ve toplumsal düzeyde kaynaşma sağlaması yönüyle sosyo-kültürel katkı sağladığıdır. Festivaller kapsamında farklı yapı ve kültürel özelliklere sahip birçok ziyaretçinin o bölgeye gitmesi; yerel halk, esnaf ve diğer katılımcılar ile iletişim kurup etkileșime geçmesi hem o bölge insanının bölgeye gelen farklı yapıdaki insanlara karşı hem de turizme yönelik algılarını olumlu yönde geliştirmesi ve o bölge insanı ve ziyaretçiler üzerinde önemli sosyal gelişmeler meydana getirmesi kaçınılmazdır. Çalışma sonucunda çıkan bulgular bu yönüyle literatürdeki benzer çalışmalar ile desteklenir niteliktedir (Giritlioğlu, Atınç, \& Özekici, 2015; Chang, 2006; Litvin \& Fetter, 2006). Bu hususta festival düzenleyicileriyle beraber bölgedeki yerel yönetimler festivallerin düzenlenme aşamasında entegre çalışarak çeşitli etkinlik ve tanıtım faaliyetleriyle bölgelerine ait kültürel değerlerin ve ürünlerin tanıtılması, katılımcıların birbirleriyle etkileşim ve iletişime geçebileceği alan ve uygulamaların düzenlenmesi, bölgenin sosyo-kültürel gelişimine katkı sağlayacaktır.

Bunu yanı sıra yerel yöneticilerin, film festivali katılımcılarından biri olan yönetmenlere bölge ile ilgili çalışma yapma teklifinde bulunması ya da yönetmenleri bölgelerinde bir çalışma yapmaya teşvik etmeleri, bölgenin sosyo-kültürel anlamda farklı coğrafyalarda da tanıtılmasını sağlayacak ve o bölgenin önemli bir kültürel turizm destinasyonu haline 
dönüşmesine ön ayak olacaktır. Çalışmaya katılan yönetmelerin görüşleri doğrultusunda çıkan bir diğer sonuç ise film festivallerinin düzenlendiği bölgeye ve bölge turizmine yönelik imaj ve tanıtıma katkı sağladığıdır. Katılımcılar film festivallerinin düzenlendiği bölgenin ulusal ve uluslararası alanda bilinirliğinin sağlanması, bölgenin sosyal medyada paylaşımının yapılması, medya ve kitle iletişim araçlarının ilgisini çekme, bölgeye kimlik kazandırma ve marka şehri olma hususunda katkı sağladığını belirtmişlerdir. Yapılan çalışmalar (Lee, Lee, Lee, \& Babin, 2004; Rivera, Hara, \& Kock, 2008; Kim, Prideaux, \& Chon, 2010) festivallerin destinasyon imajını arttırdığı, bölgeye kent kimliği kazandırdığı, marka değerini yükselttiği ve bölgenin medya ile çeşitli mecralarda bilinirlik düzeyini arttırdığını kanıtlamaktadır. Bu yönüyle literatürde yer alan bilgiler, bu çalışma kapsamında çıkan sonuçları destekler niteliktedir. Film festivallerinin hem düzenlendiği bölgeye ve bölge turizmine yönelik etkilerini olumlu düzeyde arttırmak hem de sinema sektörünün varlığını ve görünürlügünü sağlamak adına film festivallerinin olumlu yönde etkileyip sürdürülebilirliğini sağlamak için birincil paydaş olan yönetmenlerin görüşleri dikkate alınarak şu öneriler verilebilir;

- Şehrin tanıtım ve reklamının başarılı bir şekilde yapılabilmesi için finalistler, sinema yıldızları, yönetmenler ve yapımcılar festivale davet edilmelidir.

- Festivalin düzenlendiği bölgedeki kültürel turizm unsurlarının tanınırlı̆̆ının sağlaması için o bölge de film çekimlerinin ve ortak projelerin yapılması teşvik edilmelidir.

- Sektörde duayen usta oyuncu, yönetmen ve finalistlerin bir araya getirilerek katılımcılara bilgi alışverişi ortamının oluşturulması ve katılımcılara söyleşi imkânı sunulması gerekmektedir. Bu sayede film festivalleri düzenlendiği bölgeye sosyokültürel etkiler sağlayabilecektir.

- Tecrübe sahibi profesyoneller komiteye dahil edilerek program ve akış konusunda dünyanın önde gelen film festivallerini referans alarak şehrin değerlerini ön plana çıkaracak şekilde planlama yapılmalıdır. Bu sayede film festivallerine olan katılımcı düzeyinde kalite sağlanarak hem film festivallerinin etkinliği arttırılabilir hem de düzenlendiği bölgeye sosyo-kültürel ve tanıtım-imaj yönüyle katkı sağlanabilir.

- Festival süreleri uzun tutularak festival kapsamında şehrin tarihi ve turistik alanlarına geziler düzenlenmelidir. Böylelikle film yapımcıları, yönetmenler ve oyuncuların içinde bulunduğu kitleler tarafından bölgenin tanıtımının yapılması sağlanacaktır. Hem de bölgenin kültürel turizm destinasyonu olma yolunda önü açllacaktır.

- Festival düzenleyicileri yerel yönetimler ilgili kurumlarla iş birliği halinde çalışmalı, festival kapsamında şehrin tanıtımının yapıldığı gösterim oturumlarının düzenlenmesi yönetmenlerin o şehirde film yapma isteği ve arzusunu arttırabilecektir.

- Film gösterimlerinin şehrin farklı yerlerinde, farklı salonlarda yapılması katılımcıları şehre yayarak şehrin kültürel değerlerini yaşayarak öğrenmeleri açısından önem teşkil etmektedir. Örneğin Altın Koza Film Festivali her yıl Türk sinemacıların yanı sıra Avrupa'dan da yaklaşı 700 konuğu ağırlamakta ve her yıl yaklașı 70 bin izleyiciye ulaşmaktadır. Bu hususta festivalin düzenlendiği Adana bölgesinin kültürel değerlerini konuklara ve izleyicilere sunmak için önemli bir platform olarak kullanılmalıdır.

- Festival düzenleme kurulu ile yerel yönetimin, gösterimlerin ve etkinliklerin duyurularını iyi yapmaları, medyanın ilgisini çekmek için yeni stratejiler geliştirmeleri ve katılımcılara değer verip sağlıklı koşullarda misafir etmeleri festivallerin sürdürülebilirliği konusunda önemli bir unsurdur. 
- Film festivalleri kapsamında düzenlenen bölgenin kültürel unsurlarının sunulması bölgenin, diğer bölgeler arasında bilinirliğini üst konuma çıkaracaktır. Örneğin Adana'da düzenlenen Altın Koza Film Festivali Çukurova'nın geleneksel ürünü pamuğu simgelerken Antalya Altın Portakal Film Festivali ise Antalya'nın portakalını simgelemektedir. Film festivalleri logolarında kullanılan bu iki simge hem festivallerin destinasyonlarla beraber akılda kalmasını hem de festivaller sayesinde destinasyonun geleneksel ve kültürel unsurlarının insanların zihninde yer etmesini sağlamaktadır.

- Yerel yönetimler, festivali kendi ideolojileri doğrultusunda kullanmadan, kendilerinden sonraki yönetimler tarafından da sürdürülebilir olması için sağlam temellere oturtarak yapmalıdır. Aynı zamanda festivali, şehirde yaşamını sürdüren tüm sosyo-ekonomik gruplardaki ve şehrin her bölgesindeki insanlara ulaşılır kılmalı, tanıtımını iyi yapmalı ve şehirdeki üniversitelerle iş birliği yapmalıdır. 0 şehirde hem yeni sinemacıların çıkmasını hem iyi sinema seyircisinin yetişmesini hem de o şehrin bir sinema platosu olma potansiyelini öne çıkarmak için atılacak bu adımlar önemlidir.

Film Festivalleri ve turizmin özellikle kültür turizmin bir arada değerlendirildiği bu çalışma, ortaya koydukları eserleri ile milyonların gözünde kanaat önderi olan yönetmenlerin görüşlerini değerlendirmektedir. Çalışma bu yönü ile literatürde ilk çalışma olacağı için diğer çalışmalardan özgün ve farklıdır. Araştırma sonuçları kullanılan ölçme aracı ve katılımcıların verdiği cevaplar ve nitel analiz ile sınırlı olup konunun daha geniş örneklemde ve nicel yöntemlerle araştırılması bu konu üzerinde çalışma yapacak olan araştırmacılara önerilmektedir.

\section{Çalışmanın Etik İzin Bilgileri}

Karabük Üniversitesi Rektörlügü Sosyal ve Beșeri Bilimler Araștırmaları Etik Kurulu 04/11/2020 tarih ve 2020/12-18 no'lu toplantısında alınan karar çerçevesinde çalışma etik açıdan bir sakınca içermemektedir.

\section{Notlar}

1 Bu liste FIAPF akreditasyonu almış film festivalleri baz alınarak hazırlanmıştır (2008). Örnek olarak İskoçya'da gerçekleşen Edinburgh International Film Festival 1947'de kurulmuş olması ve dünyanın kesintisiz devam eden en eski film festivali olmasına rağmen FIAPF akreditasyonu olmadığı için bu listeye dahil edilmemiştir.

\section{Kaynakça}

Akgül, B. (2019). Feminist kuram perspektifinden "Kadın Filmi" olgusu: Türkiye'deki kadın filmleri festivalleri örneği (Yayınlanmamış yüksek lisans tezi). Ordu Üniversitesi: Ordu.

Antolí-Calleja, M., Orduna-Malea, E., \& Ontalba-Ruipérez, J. (2016). Customised content and impact in Website evaluation models: The case of international film festivals. Information Research, 21(1).

Aytaç, O. (2018). Film festivallerinde belgeseller ve sansür: Yeryüzü Aşkın Yüzü Oluncaya Dek ve Bakur (Yayımlanmamış Yüksek Lisans Tezi). Marmara Üniversitesi Sosyal Bilimler Enstitüsü: İstanbul.

Bikiç Çakar, N. (2018). Türkiye'de belgesel film festivallerinde film seçimlerini belirleyen etkenlere. Yeni Düşünceler, 9, 70-93.

Bilgili, B., Yağmur, Ö., \& Yazarkan, H. (2012). Turistik ürün olarak festivallerin etkinlik ve verimliliği üzerine bir araştırma (Erzurum-Oltu- Kırdağ Festivali Örneği). Uluslararası Sosyal ve Ekonomik Bilimler Dergisi, 2(2), 117-124. 
Chalip, L., \& Costa, C. (2005). Sport event tourism and the destination brand: Towards a general theory. Sport in Society, 8(2): 425-439.

Chang, J. (2006). Segmenting tourists to aboriginal cultural festivals: An example in the Rukai Tribal Area, Taiwan. Tourism Management, 27(6):1224-1234.

Crockett, S. R., \& Wood, L. (1999). Brand western australia: A totally integrated approach to destination branding. Jornal of Vacation Marketing, 5(2):276-289.

Crompton, J. L., \& Mckay, S. L. (1997). Motives of visitors attending festival events. Annals of Tourism Resarch, 24(2): 425-439.

De Valck, M. (2006). Film festivals. History and theory of a European phenomenon that became a global network. (Yayımlanmamıș Doktora Tezi). University of Amsterdam: Amsterdam.

De valck, M. (2007). Film festivals: From European geopolitics to global cinephilia. Amsterdam: Amsterdam University Press.

De Valck, M. (2008). Screening the Future of film festivals? A long tale of convergence and digitization. Film International, 6(4): 15-23.

Derrett, R. (2000). Can festivals brand community cultural development and cultural tourism simultaneously? Events beyond 2000: Setting the agenda. Proceedings of Conference on Event Evaluation. Sydney: Research And Education.

Devine, A., \& Devine, F. (2017). A Strategic Approach to International Event Tourism. N. Ferdinand, \& K. P. J. içinde, Events Management- An International Approach (s. 317333). London: Sage.

Dianne, O., \& Marion, J. (2002). Festival Tourism: A Contributor to Sustainable Local Economic Development. Journal of Sustainable Tourism, 10(4): 325-342.

Dimmock, K., \& Tiyce, M. (2001). John Wiley and Sons, Milton: Queensland Australia. D. N., \& D. R. (Eds.) içinde, Festivals and Events: Celebrating Special Interest Tourism.

Dredge, D., \& Whitford, M. (2011). Event Tourism Governance and The Public Sphere. Journal of Sustainable Tourism, 19(4-5).

Dwyer, L., Forsyth, P., \& Spurr, R. (2005). Estimating the Impact of Special Events on an Economy. Journal of Travel Research, 43(4):351-359.

Elmas, H. (2019). Film festivallerinin kısa film yapımına etkisi (Yayımlanmamış yüksek lisans tezi). Marmara Üniversitesi Sosyal Bilimler Enstitüsü: İstanbul.

Euromonitor International . (2020, 7 15). Euromonitor International sitesi: https://www. euromonitor.com/ adresinden alındı

Fredline, L., Jago, L., \& Deery, M. (2003). The development of a generic scale to measure the social impacts of events. Event Managment, 8(1): 23-37.

Getz, D. (2008). Event tourism: definition, evolution, and research. Tourism Management, 29(3):403-428.

Getz, D. (2010). The nature and scope of festival studies. International Journal of Event Management, 5(1): 1-47.

Giritlioğlu, İ., Atınç, A., \& Özekici, K. (2015). Bir Turizm Çeşitliliği Olarak Festival Etkinliklerinin Sınıflandırılması: Türkiye Üzerine Bir Değerlendirme. OÜSBAD Sosyal Bilimler Araştırmaları Dergisi, 1(1): 306-323. 
Goldblatt, J. (1997). Special Events: Best Practice in Modern Event Management. New York: Van Nostrand Reinhold.

Grunwell, S., \& Ha, I. (2008). An Empirical Study of Factors For Success. Event Managment, 11(4):201-210.

Gül, K., Erdem, B., \& Gül, M. (2013). Yerel Festivallerin Etkinliğine Bağlı Ziyaretçi Kazanımları: Sındırgı Yağcı Bedir Festivali Örneği. Süleyman Demirel Üniversitesi Íktisadi ve Ídari Bilimler Fakültesi Dergisi, 18 (2):213-239.

Gürsoy, D., Kim, K., \& Uysal, M. (2004). Perceived impacts of festivals and special events by organizers: an extension and validation. Tourism Management, 25(2): 171-181.

Harbord, J. (2009). Film Festivals-Time Event. D. Iordanova, \& R. (. Rhyne içinde, Film Festival Yearbook 1 (s. 40-46). St. Andrews: College Gate Press.

Huang, J. Z., Li, M., \& Cai, L. A. (2010). A Model of Community Based Festival İmage. International Journal of Hospitality Management, 29(2): 254-260.

Jackson, L. A. (2008). Residents' Perceptions of The Impacts of Special Event Tourism. Journal of Place Management and Development, 1(3): 240-255.

Kim, C., Scott, D., Thigpen, J., \& Kim, S. (1998). Economic impacts of a birding festival. Journal Festival Management \& Event Tourism, (5): 51-58.

Kim, S. S., Prideaux, B., \& Chon, K. (2010). A Comparison of Results of Three Stastical Methods to Understand Determinants of Festival Participants' Expenditures. International Journal of Hospitality Management, 29(2): 297-307.

Kızılırmak, İ. (2006). Türkiye'de düzenlenen yerel etkinliklerin turistik çekicilik olarak kullanılmasına yönelik bir inceleme. Sosyal Bilimler Dergisi, (15):181-197.

L. Dwyer, Forsyth, P., \& Spurr, R. (2005). Estimating the Impact of Special Events on an Economy. Journal of Travel Research, 43(4):351-359.

Landis, J. R., \& Koch, G. G. (1977). The Measurement of Observer Agreement for Categorical Data. Biometrics, 33(1): 159-174.

Lee, I., \& Arcodia, C. (2011). The Role of Regional Food Festivals for Destination Branding. International Journal of Tourism Research, 13(4): 355-367.

Lee, Y., Lee, C., Lee, S., \& Babin, B. (2004). Festivalscapes and Patron's Emotions, Satisfaction, and Loyalty. Journal of Business Research, 4(2): 56-64.

Litvin, S. W., \& Fetter, E. (2006). Can a Festival be too Successful? A Review of Spoleto, USA. International Journal of Contemporary Hospitality Management, 18(1):41-49.

Mair, J., \& Whitford. (2013). Special issue on Event and Festival Research Methods and Trends. International Journal of Event and Festival Management, 4(1).

Mazdon, L. (2007). Transnational 'French' Cinema: The Cannes Film Festival. Modern \& Contemporary France, 15(1): 9-20.

Mazza, C., \& Pedersen, J. S. (2001). From Press to E-Media? The Re Organization of an Organizational Field, 5(2).

Miller, L. G. (2004). Building The Tourism Mega-Cluster: What Works and What Doesnt't. Montreux: Executive Forum. Derrett. 
Odabasi, E. (2016). Gezici Festival: Multiple identities of a traveling film festival in Turkey. New Review of Film and Television Studies, 14(1): 149-163.

Ooi, C. S., \& Pedersen, J. S. (2010). City branding and film festivals: Re-evaluating stakeholder's relations. Place Branding and Public Diplomacy, 6(4), 316-332.

Ooi, C., \& Pedersen, J. S. (2010). City branding and film festivals: Re-evaluating Stakeholder 's Relations. Place Branding and Public Diplomacy, 6(4): 316-332.

Organ, K., Koenig-Lewis, N., Palmer, A., \& Probert, J. (2015). Festivals as Agents For Behaviour Change: A Study of Food Festival Engagement and Subsequent Food Choices. Tourism Management, (48): 84-99.

Öcal, L. (2013). Film Festivalleri ve Anlatı. (Yayımlanmamış Doktora Tezi). Marmara Üniversitesi Sosyal Bilimler Enstitüsü: İstanbul.

Özgürel, G., Alan, R., \& Bingöl, Z. (2015). Yerel Kalkınmada Bir Araç Olarak Festivaller: Munzur Kültür ve Doğa Festivali. Uluslararası Sosyal ve Ekonomik Bilimler Dergisi, 5(2): 113-121.

Özkan, E., Curkan, S. C., \& Sarak, E. C. (2015). Festivallerin Katılan Ziyaretçiler Üzerine Etkileri: Alaçatı Ot Festivali Örneği. Gümüşhane Üniversitesi Sosyal Bilimler Enstitüsü Elektronik Dergisi, 6(14).

Pasanen, K., Taskinen, H., \& Mikkonen, J. (2009). Impacts of Cultural Events in Eastern Finland-Development of a Finnish Event Evaluation Too. Scandinavian Journal of Hospitality and Tourism, 9(2-3), 112-129.

Rivera, M. A., Hara, T., \& Kock, G. (2008). Economic Impact of Cultural Events: The Case of Zora Festival. Journal of Heritage Tourism, 3(2): 121-137.

Ruling, C. C., \& Pedersen, S. J. (2008). Film festival research from an organizational studies perspective. Scandinavian Journal of Management, 26(3): 318-323.

Seçen, D. (2019). Altın Portakal Film Festivali: Ödüllü filmlerde sinematografik özellikler ve toplumsal cinsiyet temsillerinin değişimi (Yayımlanmamış Yüksek Lisans Tezi). Yaşar Üniversitesi Sosyal Bilimler Enstitüsü: İzmir.

Shyllon, F. (2007). Argungu Fishing Festival in Northwestern Nigeria: Promoting the Idea of a Sustainable Cultural Fest. International Journal of Cultural Property, (14): 329337.

Small, K., Edwards, D., \& Sheridan, L. (2005). A Flexible Framework for Evaluating the Socio Cultural Impacts of a Small Festival. International Journal of Event Management Research, 1(1): 66-77.

Statistik Austria. (2020, 6 12). Statistik Austria Web Sitesi: http://www.statistik.at/web_ de/statistiken/index.html adresinden alındı

Stringer, J. (2001). Cinema and the City: Film and Urban Societies in a Global Contex. J. Stringer, M. Shiel, , \& T. Fitzmaurice (Dü) içinde, Global Cities and the International Film Festival Economy. Oxford: Blackwell.

Sundance Institute. (2017). Sundance Institute: http://www.sundance.org/now adresinden alındı 
Şengül, S., \& Genç, K. (2016). Festival Turizmi Kapsamında Yöresel Mutfak Kültürünün Destekleyici Ürün Olarak Kullanılması: Mudurnu İpekyolu Kültür Sanat ve Turizm Festivali Örneği. Pamukkale University Journal of Social Sciences Institute(23), 7989.

Tedmem, Z. S., Kandemir, M., \& Dündar, H. (2014). Eğitim ve Bilim Dergisinde Yayınlanan Araştırmaların Eğilimleri: İçerik Analizi. Eğitim ve Bilim Dergisi, 39(173).

Thrane, C. (2002). Jazz festival visitors and their expenditures: linking spending patterns to musical interest. Journal of Travel Research, 40: 281-286.

Toronto International Film Festival . (2020, 7 28). Toronto International Film Festival Web Sitesi: https://www.tiff.net/reports/ adresinden alındı

Turan, K. (2002). Sundance to Sarajevo - Film Festivals and the World They Made. . Berkeley ve Los Angles: University of California Press.

Türten, B. (2018). Devletin kültürel ideolojik aygıtı olarak TRT ve TRT Belgesel Ödülleri'ne Althusser'ci açıdan bir yaklaşım (Yayımlanmamış doktora tezi). Atatürk Üniversitesi Sosyal Bilimler Enstitüsü: Erzurum.

Uğurlu, E. G., \& Aşkan, H. (2018). Türkiye'deki Uluslararası Film Festivalleri ve Uluslararası Eskişehir Film Festivali İzleyici Araştırması. Anadolu Üniversitesi Sosyal Bilimler Dergisi, 18(2): 81-98.

Uğurlu, H., \& Uğurlu, E. G. (2011). Uluslararası Eskişehir Film Festivali İzleyici Araştırması. Anadolu University Journal of Social Sciences, 11(3):259-276.

UNWTO. (2020, 6 12). UNWTO Web Sitesi: https://www.e-unwto.org/doi/ pdf/10.18111/9789284421152. adresinden alındı

Vienna International Film Festival. (2020, 5 15). Vienna International Film Festival: https://www.viennale.at/en adresinden alındı

Viera, A. J., \& Garrett, J. (2005). Understanding Interobserver Agreement: The Kappa Statistic. Family Medicine, (37): 360-363.

Wong, C. H. (2011). Film festivals: Culture, people, and power on the global screen. New Brunswick, New Jersey: Rutgers University Press.

Yetkiner, B. (2017). Türkiye'de film festivallerinin dönüşen yapısı (Yayımlanmamış Doktora Tezi). Atatürk Üniversitesi Sosyal Bilimler Enstitüsü: Erzurum.

Yıldırım, A., \& Şimşek, H. (2016). Sosyal Bilimlerde Nitel Araştırma Yöntemleri. Ankara: Seçkin Yayıncılık. 


\title{
The Relationship between Film Festivals and Tourism: A Study on Documentary Film Directors
}

\author{
Burak Türten (Asst. Prof. Dr.)
}

\section{Extended Abstract}

Festivals which are described as theme celebrations exhibiting worldviews, history, culture, and social identity of a living society are social activities that ensure economic, cultural, social, and artistic views convergence and promotion between communities and individuals. Undoubtedly, festivals are among the activities that are important due to attracting tourists and enriching other attractiveness of the destinations which need to contain various attractiveness elements to provide a competitive advantage and are considered as an important part of the tourism industry. That is why regions having unique festivals could be said superior compared with other destinations. Countries, cities, or districts host festivals that increasing the number of visitors and proud locals, providing economic support and enriching the image of the district, and vary in terms of purpose and containment host festivals with different functions. One of the different festival kinds is a kind of art and tourism activity which is film festivals. National or international film festivals are pieces of wire that establishes privileged economic, cultural value, and gains for organized regions. Film festivals are intermediary spaces bringing the audience seeking different films and different movies seeking the audience; different kinds of cinemas seeking market and film distributors seeking different cinemas in the world. Film festivals that act as an intermediary space, function as a cultural matrix in which intercultural perspectives are established and protected, as well as a triggering element of travels, which are the basic building blocks of tourism activities, which form the basis of satisfying people's curiosity and urge to explore. In line with this relationship between film festivals and tourism, which create a privileged economic and cultural gain for the destinations, they are organized, this study aims to determine the contribution of film festivals to the region where they are organized and to regional tourism, which is considered as a supportive product within the scope of tourism from the perspective of the directors. In the study, a qualitative research method has been adopted. The semistructured interview form used in the research has consisted of 8 open-ended questions depending on the literature review and views of academicians having a specialty in their fields. The population of the research is documentary film directors attending film festivals as a guest in Turkey. A sample has been selected as a convenient sampling method among documentary film directors residing in Turkey and has been invited five times from another city to film festivals and hosted by film festival organizations. Because of similar answers gathered, the sample has been restricted to 12 documentary film directors as conform to prior conditions. Interviews have been done between dates 1st and 30th of May 2020. Data have been analyzed with one of the qualitative research methods which is descriptive analyses and content analyses. Data have been analyzed via the computerassisted qualitative data analysis software/CAQDAS and licensed MAXQDA 2020. Within the scope of the analysis, the sentences and paragraphs obtained through the interview questions were coded and conceptualized by using the literature in a general framework, and then the obtained data were arranged and defined under thematic coding. Results are presented according to the number of participants' statements with sub-codes in the result section. In the study, the following research questions were sought to determine 
the contribution of the film festivals to the region and tourism of the region from the perspective of the directors:

1. Do organizing a film festival in a city contribute financially to touristic business (hotel, pension, restaurant, museum and archeological site, souvenir shop, etc.) in that city?

2. Do organizing film festivals in a city contribute socioculturally by providing social and cultural integration between the local people residing in that city and the festival participants?

3. Do organizing film festivals in a city have an effective role in recognizing that city and making it a brand city?

As a result of the analysis, the answers are given by the directors regarding the region where film festivals organized, which are considered as a supportive product within the scope of tourism, and their possible contributions to regional tourism were coded under three headings: "economic", "socio-cultural" and "promotion and image." Participants have mentioned possible economic effects of the film festival on organized region and its tourism with 36 statements. It has been determined that the expressions of the participants are divided into three themes of the film festivals: "off-season activity in the region, income, and increase in the number of visitors in the region." Participants have mentioned possible socio-cultural effects of the film festival on the region and its tourism with 28 statements. The expressions of the participants were divided into four themes: "The promotion and protection of the cultural heritage of the region (18), social cohesion (8), the positive influence of the local people's perspective towards the tourist (16), the interaction between the local people and the visitors (12)" has been determined. Finally, participants have mentioned the contribution of the film festival in the region and its tourism in terms of creating image and promotion with 42 statements. The statements of the participants are divided into eight themes. These are according to the high number of expression frequency; "Ensuring the recognition of the region nationally and internationally (12), sharing the region on social media (9), attracting the attention of the media and mass media (8), ensuring the awareness of the attractiveness of the region (7), contribution to the region's advertisement (5), brand city creating (4), increasing the brand value of the city (3) and giving the region an urban identity (3)". As a result, it has been determined that film festivals contribute to the region and the economy of the region in economic, socio-cultural, and promotional/image dimensions. Within the scope of the study, various suggestions were made to film festival organizers and local administrations to increase the quality and sustainability of film festivals and to increase the contributions to the regions where the festivals are held.

Keywords: Film Festivals, Documentary Film Directors, Cinema, Tourism.

Bu makale intihal tespit yazılımlarıyla taranmıştır. İntihal tespit edilmemiştir.

This article has been scanned by plagiarism detection softwares. No plagiarism detected.

Bu çalışmada "Yükseköğretim Kurumları Bilimsel Araştırma ve Yayın Etiği Yönergesi” kapsamında uyulması belirtilen kurallara uyulmuştur.

In this study, the rules stated in the "Higher Education Institutions Scientific Research and Publication Ethics Directive" were followed. 